WORKING

PAPER SERIES

ON REGIONAL

ECONOMIC

INTEGRATION NO. 24
Does Trade Integration

Contribute to Peace? 



\section{Does Trade Integration Contribute to Peace?*}

January 2009
Jong-Wha Lee ${ }^{+}$and Ju Hyun Pyun ${ }^{++}$

* We thank Robert Barro, Colin Cameron, Zeev Maoz, and seminar participants at Asian Development Bank for very helpful suggestions and Guy Sacerdoti for editorial assistance. The views expressed in the paper are the authors' and do not necessarily reflect the views and policies of the Asian Development Bank.

${ }^{+}$Corresponding author: Office of Regional Economic Integration, Asian Development Bank, 6 ADB Avenue, Mandaluyong City, 1550 Metro Manila, Philippines. Tel: +632 632 4900, Fax: +632 636 2183, E-mail: jwlee@adb.org.

${ }^{++}$Department of Economics, One Shields Avenue, Davis, CA 95616, USA, Tel: 530601 1900, E-mail: jpyun@ucdavis.edu.

\section{Asian Development Bank}


The ADB Working Paper Series on Regional Economic Integration focuses on topics relating to regional cooperation and integration in the areas of infrastructure and software, trade and investment, money and finance, and regional public goods. The Series is a quick-disseminating, informal publication that seeks to provide information, generate discussion, and elicit comments. Working papers published under this Series may subsequently be published elsewhere.

Disclaimer:

The views expressed in this paper are those of the author and do not necessarily reflect the views and policies of the Asian Development Bank or its Board of Governors or the governments they represent.

The Asian Development Bank does not guarantee the accuracy of the data included in this publication and accepts no responsibility for any consequence of their use.

Use of the term "country" does not imply any judgment by the authors or the Asian Development Bank as to the legal or other status of any territorial entity.

Unless otherwise noted, \$ refers to US dollars.

(C) 2009 by Asian Development Bank

January 2009

Publication Stock No. 
$\begin{array}{lr}\text { Abstract } & 1\end{array}$

1. Introduction 2

2. The Impact of Bilateral and Global Trade Integration on Conflict 3

3. Empirical Specification and Data 5

4. Empirical Results 8

4.1 Basic Results 8

4.2 Robustness of the Results 12

4.3 Instrument Variable Estimation 14

5. The Impact of Military Interstate Disputes on Trade Integration 16

$\begin{array}{ll}\text { 6. Concluding Remarks } & 18\end{array}$

$\begin{array}{ll}\text { References } & 20\end{array}$

ADB Working Paper Series on Regional Economic Integration 34

Tables

1. Militarized Interstate Disputes, 1950-2000 25

2. Top 15 Countries That are Most Frequently Involved in the Militarized Interstate Disputes (MID), 1950-2000 25

3. Summary Statistics 26

4. Determinants of Militarized Interstate Disputes 27

5. Robustness Check I (Inclusion of other variables) 28

6. Robustness Check II (Other trade integration measurements) 29

7. Instrument Variable Estimation: First Stage Regression 30

8. Instrument Variable Estimation: Second Stage IV Regression

9. Impact of Military Conflicts on Bilateral Trade Dependence

10. Impact of Military Conflicts on Global Trade Integration

Figures

1. The Change of Bilateral and Multilateral Trade Flows Before, During, and After Selected Incidences of Militarized Interstate Disputes (million, current USD) 


\begin{abstract}
This paper investigates the effect of trade integration on military conflict. Our empirical analysis, based on a large panel data set of 290,040 country-pair observations from 1950 to 2000, confirms that an increase in bilateral trade interdependence and global trade openness significantly promotes peace. It also suggests that the effect of trade openness varies depending on the geographical proximity of countries. The peace-promotion effect of bilateral trade integration is significantly higher for contiguous countries that are likely to experience more conflicts. The analysis shows, however, that an increase in global trade openness reduces the probability of conflict more for countries far apart from each other than it does for countries sharing borders. The results also show that military conflict between countries significantly reduces not only bilateral trade interdependence but also multilateral trade integration. The main finding of the peace-promotion effect of bilateral and global trade integration holds robust when controlling for the natural and geopolitical characteristics of dyads of states that may influence the probability of military conflict and for the simultaneous determination of trade and peace.
\end{abstract}

Keywords: Trade, Globalization, Military conflict, Peace

JEL Classification: D74, F15, F51 


\section{Introduction}

"The great extent and rapid increase of international trade, in being the principal guarantee of the peace of the world, is the great permanent security for the uninterrupted progress of the ideas, the institutions, and the character of the human race" (John Stuart Mill, Principles of Political Economy, London: Longmans, 1909, p.582).

Globalization has been one of the most salient features of the world economy over the last century. Emerging markets and developing countries continue to integrate into the global trading system. World trade has increased rapidly, particularly since World War II-from $17.8 \%$ of world GDP in 1960 to $47.4 \%$ in 2005.

There has been a long tradition among social scientists to try to understand the economic, political, and social consequences of globalization. It has always been a hotly-debated topicnot merely within academia but among the general public as well-whether globalization significantly affects economic growth, income inequality, national identity, and so on.

This paper examines the effect of trade integration on international relations, specifically military conflict between individual states (interstate conflict). Recent literature shows that military conflict can be extremely disruptive to economic activity and impede long-term economic performance (Davis and Weinstein, 2002, Blomberg, Hess and Orphanides, 2004, and Barro, 2006). In particular, they empirically study the effect military conflict has on international trade. They find that conflict between countries significantly reduces international trade and thus seriously damages national and global economic welfare (Glick and Taylor, 2006, Blomberg and Hess, 2006 and Martin, Mayer and Thoenig, 2008). However, the opposite relationship between international trade and the probability of interstate military conflict-whether international trade has any significant impact on conflict-has not been clearly assessed.

Does trade integration contribute to peace? There are at least two important issues underlying this question. The first is to distinguish between bilateral trade interdependence and global trade integration. ${ }^{1}$ If trade integration occurs in a way of increasing trade interdependence uniformly with all bilateral trade partners, the distinction between bilateral and global trade integration is not critical. However, deeper integration into global markets can take place even with lowering trade interdependence with some trading partners. The overall impact of trade integration on interstate conflict is likely to depend not only on the change in bilateral trade interdependence but also on global trade integration.

The second issue concerns whether the effect of trade integration on interstate conflict varies depending on characteristics of dyads, or specific pairs of states. For instance, neighboring states are likely to be engaged in more trade and disputes, whereas for nations geographically far apart, or distant states, interstate trade and political relations tend to be less intense. Thus, an increase in bilateral and global trade integration may affect dyads of states differently depending on geographical distance. Greater bilateral trade interdependence can be more helpful in promoting peace for countries closer geographically by preventing disputes from escalating into military conflicts. From another angle, it can be conjectured that for geographically distant countries banded together in a global conflict (rather than local conflict), an increase in global trade openness might reduce the probability of military conflict between them more significantly than for countries closer geographically.

The phrase "global trade integration" implies "trade openness," which is often measured by the ratio of total trade to GDP at the aggregate national level. 
While several previous empirical studies have investigated the effect of trade integration on military conflict between countries, there is no systematic empirical research assessing the peace-promotion effect of both bilateral trade and global trade integration-and its interaction with geographical characteristics of states. Although a number of studies have addressed this issue, there remains a lack of consensus. ${ }^{2}$ This paper attempts to fill this gap and produces novel results.

An empirical assessment of the impact of trade integration on military conflict is done based on regression equations utilizing a panel data set of dyadic observations from 1950 to 2000. The results show that an increase in bilateral trade interdependence and global trade integration significantly promotes peace between countries. The strong positive effect of global trade openness on peace is a novel finding, contrasting the result of Martin et al. (2008). We also find that the impact of trade integration on military conflict varies depending on the geographical proximity between countries. Bilateral trade interdependence promotes peace more significantly for contiguous countries, whereas global trade openness contributes more to peace between distant countries. The results also show that geopolitical factors such as bilateral distance, alliance commitment, joint democracy, oil exports, and religious similarity influence the probability of military conflict among dyads of states.

The paper is organized as follows. Section II briefly discusses the effect of bilateral trade interdependence and global trade integration on military interstate conflict. In Section III, we explain data and the empirical methodology for evaluating the effects of bilateral and global trade dependence on the probability of military conflict. Section IV presents and discusses the estimation results. Section $V$ analyzes the impact of military conflict on bilateral and global (multilateral) trade integration. Concluding remarks follow in Section VI.

\section{The Impact of Bilateral and Global Trade Integration on Conflict}

There is ongoing debate among scholars whether the increase of bilateral economic interdependence reduces interstate conflict. The "liberal peace" view in political science-traced back to Montesquieu, Kant, Angell, and Schumpeter-emphasizes that mutual economic interdependence can be a conduit of peace. It suggests that a higher degree of bilateral economic interdependence limits the incentive to use military force in interstate relations. For instance, a state more trade-dependent is less likely to fight a partner because of the larger opportunity cost associated with the loss of trade. Business elites-who gain most from an increased economic interdependence-will also lobby the state to restrict the use of military force against an important trading partner.

While the "liberal peace" view is convincing, there are numerous counter-arguments. For instance, the Dependency theorists (Wallerstein, 1974) and neo-Marxists (Emmanuel, 1972), argue that asymmetric economic interdependence could lead to negative consequences in a country-such as exploited concession and threatened national autonomy-thereby creating interstate tensions and conflicts (Dos Santos, 1970 and Keohane and Nye, 1973). Many wars in history evolved out of trade disputes.

Empirical studies have also investigated whether bilateral trade interdependence increases or reduces the likelihood of military conflict between trading partners. Similar to theoretical literature, the findings of these studies are ambiguous. Earlier studies, such as Polachek (1980)

See Section II for a brief survey of these studies. 
and Polacheck, Robst, and Chang (1999), show that there is negative relationship between bilateral trade volume and the frequency of interstate military conflict. However, Barbieri (1996) and Barbieri and Schneider (1999) investigate the relationship between various measures of bilateral trade links and military conflict. They find that a measure of bilateral trade interdependence has a significantly positive impact on military conflict. In reverse, subsequent research-including Oneal and Russett (1999) and Gartzke and Li (2003)-show that with the use of a different measure of bilateral trade interdependence, the interdependence appears to reduce military conflict.

In contrast to the numerous studies on the impact of bilateral trade interdependence on military conflict, there are only a few studies examining the role that global trade openness plays. An increase in global trade openness is expected to reduce the probability of military conflict as it leads to an increase in the extent of bilateral trade interdependence. However, when the level of bilateral trade interdependence is controlled, the effect of increased global trade openness on the probability of bilateral conflict is not clear. Barbieri and Peters (2003) find "trade openness" has a significantly negative impact on the probability of military conflict. In contrast, Martin et al. (2008) show that "multilateral openness," that is, global trade openness, increases the probability of military conflicts.

In general, open states can be more peaceful because they become more susceptible to political freedom and democracy. They apply international law better and employ good governance. Trade openness can also lead to an "expansion of bureaucratic structure," which is concerned about economic interests in addition to security interests-and thus less likely to resort to military actions (Domke, 1988). Moreover, more open economies tend to be small in size, and thus have smaller incentive to engage in wars.

However, Martin et al. (2008) argue that countries more open to global trade have a higher probability of dyadic conflict because multilateral trade openness reduces bilateral dependence to any given country and thus lowers the opportunity cost of military conflict. Their model assumes that a bilateral military conflict between countries destroys a substantial part of the "effective labor" in them, while it increases both bilateral and multilateral trade costs. Higher multilateral trade offsets welfare loss from decrease in effective labor during a bilateral conflict, thus reducing the opportunity cost of bilateral conflict. On the other hand, higher multilateral trade increases the opportunity cost of the bilateral conflict by raising multilateral trade costs. They further assume that the increase in multilateral trade costs following a conflict is small enough compared with the welfare loss due to the decrease in the number of consumption varieties that result from the loss in effective labor. It is a critical assumption to guarantee that the high level of multilateral trade has a positive impact on the probability of military conflicts. ${ }^{3}$ The opportunity cost of bilateral conflict would become smaller if greater global openness helps mitigate the loss of consumption during a military conflict by substituting for decreased domestic production as well as imports from the fighting countries. However, closed border and increased

3 Refer to equation (9) in Martin et al. (2008):

$\operatorname{Pr}\left(\right.$ escalation $\left._{i j}\right)=1-\frac{1}{V^{2}}\left\{\frac{\sigma \lambda}{\sigma-1}+\tau_{b i l} \frac{m_{i j}}{E_{i}}-\left(\frac{\lambda}{\sigma-1}-\tau_{\text {multi }}\right) \sum_{h \neq j, i}^{R} \frac{m_{i h}}{E_{i}}\right\}^{2}$ where, $\lambda$ is the loss of effective labor by conflict (\%), $\sigma$ is an elasticity of substitution between consumption varieties, $\tau_{\text {multi }}$ is multilateral trade cost. The paper assumes $\left(\frac{\lambda}{\sigma-1}-\tau_{\text {multi }}\right)>0$ (by high $\lambda$, low $\sigma$ and relatively small $\tau_{\text {multi }}$ ) in order to draw the prediction that the high level of multilateral trade has a positive impact on the probability of escalation to war. 
resource cost following a bilateral military conflict often lead to a substantial increase in multilateral trade costs, nullifying the assumption.

In addition, their model does not consider the possibility that a war provoked by a state against one trading partner can lead to a reaction from one or more other trading partners. As long as other trading partners in global markets prefer to do business with a peaceful partner, a dyadic conflict would have a negative consequence on the dyad's trade with global partners. This suggests that global trade openness of the dyad can in fact reduce the incentive to provoke a bilateral conflict.

Figure 1 shows the change of bilateral and multilateral trade flows of four warring dyads before, during, and after the conflict between them. The bilateral conflicts between countries were typically followed by a decrease, not only in bilateral trade flows, but also in multilateral trade. During military conflicts, multilateral trade declined quite notably in both states. In terms of postconflict multilateral trade, the state that lost the war (in terms of international perception) suffered a more significant decline. While this data is merely suggestive, we will employ a more formal empirical analysis to assess the effects military conflict has on multilateral trade (see Section V).

\section{Empirical Specification and Data}

We investigate the impact of trade integration (bilateral and global) on military conflict based on regression equations utilizing panel data of dyadic observations from 1950 to 2000:

$$
Y_{i j t}=\alpha+\beta_{1} \times \text { Bilateral trade }_{i j t}+\beta_{2} \times \text { Global trade }_{i j t}+\gamma X_{i j t}+\delta \times \text { Year }_{t}+u_{i j t}
$$

where the dependent variable, $Y_{i j t}$, equals unity if state $i$ and $j$ are engaged in a military conflict against each other at time $t$ and equals zero otherwise, Bilateral trade $e_{i j t}$ is a measure of bilateral trade interdependence between the dyad of states $i$ and $j$, Global trade $e_{i j t}$ is a measure of trade dependence of the dyad on global markets (except the bilateral partner), the vector $X_{i j t}$ comprises the other important determinants of interstate conflicts, and $Y_{e a r}$ denotes a set of binary variables that are unity in year $t$.

The measure of military conflict is constructed from the database of the "Correlates of War (COW)" project. ${ }^{4}$ This dyadic data set codes of all Military Interstate Disputes (MID) with a level of hostility ranging from 1 to 5 (1= no militarized action, 2= threat to use force, $3=$ display of force, $4=$ use of force, $5=$ war). This MID dataset (version 3.02) is transformed to dyadic events with corrections made by Zeev Maoz (Maoz, 2005). ${ }^{5}$

Table 1 shows the characteristics of the data set. In the sample of 572,246 dyadic observations from 1950 to 2000, MID events of levels 2, 3, 4, and 5 total 2,405, out of which wars of level 5 comprise only 264 .

Our sample for regressions is restricted because of the limited availability of explanatory variables. In the sample of 290,040 observations, MID events total 1,593, with 75 wars. For our measure of the dependent variable, we use the broadest concept of military conflicts--

http://www.correlatesofwar.org/

The data set and codebook are available from http://psfaculty.ucdavis.edu/zmaoz/dyadmid.html 
comprising all MID events of hostility levels 2, 3, 4, and 5 . If the definition of military conflicts is restricted to interstate wars of level 5 (or 4 and 5 ) only, the smaller number of military conflicts hinders creation of robust empirical estimates. ${ }^{6}$

The indicator used to capture bilateral trade interdependence is the geometric average of bilateral trade flows over GDP of two countries. For global trade openness, we use the geometric average of total trade (excluding their bilateral trade flows) over GDP of two countries. Data on trade measured in current US dollars for 1948-2000 are from Gleditsch (2002), ${ }^{7}$ which originate from the International Monetary Fund (IMF) Direction of Trade database and other sources. Data on GDP in current US dollars are from IMF, International Financial Statistics and, Barbieri (2002) Dataset ${ }^{8}$ for 1950-1965, and World Bank, World Development Indicators for 1965-2000. We use values lagged 2 years to limit simultaneity problems.

The specification also controls the other important determinants of interstate conflicts that are identified by previous literature. These control variables include geographical proximity, relative military power, and political and cultural factors. Military conflicts are expected to occur more often between neighboring countries because they are more likely to be engaged in disputes and they can mobilize military resources against each other more quickly. To measure geographical proximity, we use two variables-(i) the log of bilateral distance between countries and (ii) a binary variable for contiguity (by land and by sea up to 150 miles) between them. These variables are from the COW database.

Relative military capabilities between states have a significant impact on the probability of military conflict. But it is not clear in theory whether power preponderance or power balance is more conducive to peace. Empirical studies, on the other hand, broadly support the view that states more equally balanced in military power are less inclined to engage in military conflict. We include the log difference of GDP as a measure of relative military power on interstate relationships.

In addition, the role of "major power" countries is considered. States with foremost military power are more likely to undertake military actions against less powerful states to exploit concession, or to interfere and mediate conflicts in the world. A binary variable for a group of major power countries is added for five United Nations (UN) Security Council membersPeople's Republic of China, France, United Kingdom, United States, and USSR (Russia Federation).

Political factors that affect the probability of military conflict include the characteristics of political institutions such as democracy. In political science literature, including those of the "liberal peace" view, nations with higher levels of democracy are less likely to engage in war. The democratic process necessitates more discussion and majority support from the public and the legislature in making major decisions such as war (Dixon 1993, and Oneal et al. 1996). For measurement, an index for joint democracy is used (Bremer 1993). The raw data is from Polity IV database, ${ }^{9}$ which assesses each country's level of democracy ranging from full autocracy ($10)$, to full democracy $(+10)$. The joint democracy variable is constructed by multiplying two

Estimations were conducted at MID events of levels 3, 4, and 5 only and found qualitatively similar results.

http://privatewww.essex.ac.uk/ ksg/exptradegdp.html

http://people.cas.sc.edu/barbierk/databases.html

The Polity IV Project (Political Regime Characteristics and Transitions, 1800-2004), under the direction of Monty G. Marshall at George Mason University, carries data and analysis through 2006 (http://www.cidcm.umd.edu/polity/data/). 
countries' indexes and then rescaling them to range from 0 to 1 , with unity indicating dyads with two full democracies. We also include a binary variable for the presence of formal security alliances for dyads. This variable comes from the COW database.

Cultural and religious factors are often argued as the root cause of interstate conflict. In his book, The Clash of Civilizations and the Remaking of World Order (1996), Samuel Huntington argues that in the post-Cold War world, conflicts between different civilizations increasingly replaced those of differing ideologies. Religious difference often leads to interstate conflict due to fundamentalism and "securitization of faith" (Lausten and Wæver 2000). Recent conflicts such as the US-Iraq war and the Kosovo conflict support these arguments. Several empirical studies investigate the relationship between religious similarity and interstate conflict and provide mixed results. An early study by Henderson (1998) shows religious similarity tends to reduce the frequency of interstate wars. In contrast, Russet et al.(2000) and Chiozza (2002) find civilization differences do not have a significant influence on interstate militarized disputes.

While these previous studies adopt a measure of religious similarity based on detailed religion categories, we construct a new measure of religious similarity between dyads by focusing on nine major religions ( $\mathrm{k}=$ Catholic, Protestant, Other Christianity, Orthodox, Islam, Buddhism, Hinduism, "Eastern" religions, and Judaism). The index is defined as

$$
1-\sum_{k}\left|R_{i}^{k}-R_{j}^{k}\right|
$$

where $R_{i}^{k}$ and $R_{j}^{k}$ denote the fraction of the religion $k$ in the population of country $i$ and $j$ respectively. ${ }^{10}$ The index is similar to the ' $S$ ' index (Signorino and Ritter, 1999) or the 'affinity of nations' index (Gartzke, 2000) and measures the extent to which two countries share the same religious affiliations. It ranges between -1 (most dissimilar) and 1 (most similar). The raw data comes from Barret $(1982,2000)^{11}$ and Barro (2006). By considering only the nine major religions, we assume that the differences in nonreligious and other religion populations do not influence conflicts between states.

The specification also considers the impact of natural resource endowment on interstate conflict by including an oil-exporter dummy variable. The argument that conflicts are often linked by control over ownership of resources or the means to access and to market them (such as trade routes) has a long history-since the era of mercantilism and colonialism. In particular, energy resources such as oil have been a major cause of interstate conflict, for example, the 19801988 Iran-Iraq war (Klare 2001). The oil-exporter dummy is 1 if one of the dyads belongs to OPEC. Oil-net exporters are likely to be exposed to more conflicts involving their resources.

Table 2 reports the top 15 countries that were most frequently involved in military interstate dispute (MID) events from 1950 to 2000. The top three countries-US, Russia (USSR and Russian Federation), and People's Republic of China-belong to the "major power" category.

10 Guiso et al.(2005), and Helpman et al.(2008) also consider only major religions to construct a measure of religious similarity. But their measure is constructed by adding up the multiplications of two countries' population shares across each religion category. Hence, the index ranges from 0 (most dissimilar) and 1 (most similar). This measure is problematic because, for instance, for a majority of dyads consisting of a country which has very small population shares in all four major religions it has a value always very close to 0 (most dissimilar) regardless of the religions in the other country, predicting counterintuitively that the dyads are most likely to engage in interstate conflict (as much as other dyads in which two countries are completely different in major religions). In contrast, our measure will have different values based on the degree of similarity between dyads in nine categories.

11 http://worldchristiandatabase.org/wcd/default.asp 
The other two major powers are ranked $11^{\text {th }}$ (United Kingdom) and $15^{\text {th }}$ (France). Also, Middle East countries ranked high-Iran $\left(4^{\text {th }}\right)$, Israel $\left(5^{\text {th }}\right)$, Iraq $\left(6^{\text {th }}\right)$, Syria $\left(8^{\text {th }}\right)$, Turkey $\left(9^{\text {th }}\right)$, and Egypt $\left(10^{\text {th }}\right)$. They have been involved in more conflicts because of religious differences, resources, and geopolitical factors. India and Pakistan, wichh differ in major religion and are embroiled in a dispute over Kashmir, rank $7^{\text {th }}$ and $13^{\text {th }}$ respectively. Thailand $\left(12^{\text {th }}\right)$ and the Republic of Korea $\left(13^{\text {th }}\right)$ are also involved in many conflicts, mostly with adjacent countries. The top 15 countries participated in 813 out of 1,458 total MIDs during the period. The table shows that geopolitical factors, major power, religion, and oil exports are important factors for military conflicts.

The regression includes time dummies to control for common effects of external factors such as the end of the Cold War. The variable $u_{i j t}$ is a random error term. All time-varying variables are lagged by 2 years to limit simultaneity problems.

The data set has a feature of panel structure consisting of 290,040 annual observations clustered by 14,190 country pair groups from 1950 to 2000 . The number of observations varies by year.

Because a conflict is a binary-choice variable, we use pooled logit model to explain the variable. To estimate these systems, we allow for clustering for common country-pair observations of the error terms over time. ${ }^{12}$

Summary statistics for the entire data used in the estimation are presented in column (1) in Table 3. Of all the observations in the sample, 1,593 country-pairs (about $0.55 \%$ ) belong to a conflict and 288,447 (about 99.45\%) to non-conflict or peace. Columns (2) and (3) of Table 1 report summary statistics for each sub-sample.

In Table 3, we observe that conflicts have been more frequent among dyads of states sharing a common land border or are geographically closer. The mean of contiguity index (the logarithmic distance) is higher (smaller) in column (2) than that in column (1).

The mean of (lagged) bilateral trade interdependence measure in column (2) is three times higher than that in column (1), indicating that the bilateral trade between dyads in conflict is much higher than the average bilateral trade in the entire sample. On the other hand, the mean of (lagged) global trade openness measure in column (2) is slightly smaller than that in column (1), which implies that conflicts have occurred more frequently among dyads of states relatively more open with each other but less open to the global economy. This casual observation does not imply that greater bilateral trade interdependence or lesser global trade openness leads to more conflict between dyads. When the relationship between each variable and conflict is discussed, the other variables should be appropriately controlled. For example, the shorter distance between dyads in conflict naturally leads to greater bilateral trade interdependence and smaller global trade openness.

\section{Empirical Results}

\subsection{Basic Results}

Similar results are derived from random-effects models, although the bilateral trade interdependence becomes less statistically significant. These results are not emphasized here because the conditions needed for the satisfactory implementation of random-effects logit models seem unlikely to hold. See Wooldridge (2002). 
Table 4 presents estimation results for the logit model for the probability of conflict. Consider first the results in columns (1)-(3). Column (1) includes bilateral trade interdependence variable. Column (2) substitutes the global trade openness for the bilateral trade interdependence. Column (3) includes both of these trade integration variables.

Column (1) of Table 4 shows that the model fits the data well, explaining a substantial part of the variation in the occurrence of military conflict. Bilateral distance, contiguity, joint-democracy, relative military capabilities, and major-power variables are individually significant at the $1 \%$ critical level. The significantly negative estimated coefficient for the bilateral distance and the significantly positive one for contiguity explain that geographically proximate countries are more likely to engage in military conflict. The positive estimate for log difference of GDP supports the contention that states unequally balanced in military capability are less likely to engage in military conflict. On the other hand, the positive estimated coefficient on major-power variable explains that these countries tend to fight more. The negative estimate for joint democracy confirms that the probability of military conflicts is significantly lower for dyads composed of states that are more democratic.

In column (1), the estimated coefficients on formal security-alliance, religious similarity and oil exporters dummy variables show the signs supporting the theoretical predictions, but turn out to be statistically insignificant. Finally, the estimated coefficient on bilateral trade interdependence is negative and statistically significant at the $5 \%$ level, indicating that bilateral trade dependence significantly decreases the probability of military conflicts. Most importantly, this estimation result holds true with all other important variables being controlled. For instance, distance affects both bilateral trade and conflict probability negatively. ${ }^{13}$

In column (2) of Table 4, the estimated coefficient on global trade openness is negative and statistically significant. Dyads of states more dependent on the world economy tend to have fewer conflicts than those less dependent. This result contrasts that of Martin et al. (2008) and holds quite robust as discussed later. As our specification includes a time dummy variable separately, this significant coefficient may not be caused by global factors such as the end of Cold War or peace-promotion efforts of international organizations that are common to all countries. In this specification, the estimated coefficients on formal security-alliance and oil exporters dummy variables turn out to be marginally significant at the $10 \%$ and $5 \%$ critical levels respectively. Oil exporters are involved with military conflicts more frequently. Alliance commitments tend to reduce the probability that dyads engage in conflict.

In column (3) of Table 4, in which both global trade openness and bilateral trade interdependence are included, global trade openness has individually significantly negative effects at the $1 \%$ critical level. The estimated coefficient on bilateral trade interdependence is also significant at the $5 \%$ critical level. Broadly speaking, both bilateral and global trade dependence promote peace between bilateral trade partners. Hence, this result refutes Martin et al. (2008)'s argument that countries more open to global trade have a higher probability of war by increasing the probability of escalation for proximate countries.

In the logit model, the dependent variable is defined as the log-odds ratio and the parameters do not correspond to the marginal effects of independent variables. The marginal effects can be

The omission of distance in the regression yields a biased (toward to a positive value) estimate of the impact of bilateral trade interdependence on conflict. A positive estimate of the impact of bilateral trade interdependence on conflicts which was obtained often by some researchers such as Barbieri (1996) can be attributed to this bias. 
calculated at the means of regressors by using the estimate. ${ }^{14}$ Then, we can compute the response of the probability of military conflict to a one-standard-deviation change of each explanatory variable, gauging the relative importance of each explanatory variable in influencing the probability of military conflict.

For example, based on column (3) of Table 4, an increase in the log of bilateral trade dependence by one standard deviation of 0.008 (starting from the sample mean) decreases the probability of military conflict by 0.019 percentage point, with other variables held constant. On the other hand, an increase in the log of global trade openness (by one standard deviation, or 0.380 ) decreases the probability of military conflict by 0.109 percentage point. Hence, global trade openness, compared with bilateral trade dependence, has a relatively large impact on the probability of conflict with the bilateral trade partner.

Geographic proximity also has a large impact on the probability of military conflict. An increase in the log of bilateral distance by 0.824 (its standard deviation) is associated with a decrease of the likelihood that a pair of countries is engaged in a conflict by 0.069 percentage point. Since the contiguity variable is an indicator variable, its marginal impact is calculated for its change from 0 (no common land or distant by sea above 150 miles) to 1 (common border or distant by sea up to 150 miles). The corresponding response to this change is an increase in the probability of military conflict by 0.421 percentage point. Hence, the probability of a military conflict is substantially higher for contiguous countries.

An increase in the log difference of GDP (by one standard deviation or 1.844) generates an increase in the probability of conflict by 0.034 percentage point. The corresponding response to an increase in the joint-democracy index (by one standard deviation or 0.331 ) is by 0.057 percentage point.

The marginal impacts of the major-power and oil-exporter variables correspond to the change of these dummy variables from 0 to 1 . The probability of military conflict increases by 0.29 percentage point responding to the change in the major-power variable and by 0.064 percentage point when at least one of dyads is an oil exporter. Hence, the probability of military conflict is substantially higher between dyads that involve a major power. The marginal impact of religious similarity (by one standard deviation or 0.566 ) decreases the probability of conflict by 0.016 percentage point.

The empirical technique used assumes that there is no unobserved country-fixed factor. Column (4) of Table 4 presents the result from the "conditional" fixed-effects logit estimation technique which controls for unobservable country-pair fixed effects. The result with country-pair fixed effects show that while most of estimated coefficients show the same signs as those in the pooled logit regressions, they are not statistically significant. On the contrary, the estimated coefficient on religious similarity becomes larger and statistically significant at the $1 \%$ level. Although fixed-effects estimation is often preferred by many researchers, the fixed-effects technique also has drawbacks. Because the fixed-effect estimator exploits only the variation over time, the estimates for time-invariant factors such as distance, contiguity, oil-exporters and major powers dummy cannot be obtained. By eliminating entire information from cross-section

14 The log of odds ratio is $\ln \left(\frac{P(y=1 \mid x)}{1-P(y=1 \mid x)}\right)$, where $P(y=1 \mid x)=\frac{e^{\beta^{\prime} x}}{1+e^{\beta^{\prime} x}}=\Lambda\left(\beta^{\prime} x\right)$. The marginal effect $\left(\frac{\partial P(y=1 \mid x)}{\partial x}\right)$ is derived by $\frac{\partial P(y=1 \mid x)}{\partial x}=\Lambda\left(\beta^{\prime} x\right)\left[1-\Lambda\left(\beta^{\prime} x\right)\right] \beta \quad($ see Greene, 1993, Chapter 21). 
variations, the estimation relies on a smaller information set. In column (4), the sample shrinks to only 15,589 . In addition, it may exacerbate the bias due to measurement errors in variables.

A number of previous studies also include the number of peace years (since the last MID) variable to the regression to control "temporal dependence" between conflict events.(Beck et al, 1998) It is suggested that the temporal dependence problem which means an auto-correlated binary dependent variable can mislead the result of logit analysis. For instance, military conflicts, which can be durable more than a year, can occur with different probability if they are subsequent. Column (5) presents the estimation result. Now, the religious similarity variable becomes significant at the $5 \%$ critical level. Countries whose major religions are similar are less involved in conflicts. The estimated coefficients also show that global trade openness has a significantly negative effect at the $1 \%$ critical level, while bilateral trade interdependence variable becomes only marginally significant at the $10 \%$ critical level.

Our specification assumes that the impact of bilateral or global trade openness on the probability of military conflict is the same for all country pairs independent of other country-pair characteristics. But trade patterns (bilateral and global trade openness) may affect the probability of military conflict differently for different subsets of countries, depending in particular on the geographical distance between them. For example, the peace-promotion effect of bilateral trade interdependence may occur more heavily for geographically closer countries that are more likely to be engaged in conflicts. Greater bilateral trade dependence can help prevent proximate countries from being escalated into military conflicts. In contrast, it is less clear if greater global trade openness reduces the probability of escalation.

In order to investigate this possibility, a test is conducted on whether the impact of bilateral or global trade openness on the probability of military conflict depends on bilateral distance or contiguity between dyads.

First, two interaction terms of bilateral distance with the bilateral and global trade integration variables are introduced to the regression. The estimated result in column (6) confirms that the impact of bilateral trade openness varies depending on the distance between countries. While the estimated coefficient on bilateral trade dependence, $(-122.48$ s.e. $=25.77)$ is negative and statistically significant, the estimated coefficient on the interactive term between bilateral trade interdependence and distance $(16.95$, s.e. $=3.37)$ is positive and statistically significant. These two estimates combined suggest that the closer two countries are, the greater is the peacepromotion effect from an increase in bilateral trade. In fact, the overall marginal effect of bilateral trade interdependence on the probability of military conflict is negative between proximate countries and then positive between distant ones. The two estimated coefficients imply that the switch occurs at log of bilateral distance of 7.22 which is below the sample median of 8.88 . The strong negative relation between bilateral trade interdependence and the probability of military conflict in dyads with smaller bilateral distance seems to support the argument that greater bilateral trade interdependence can be helpful to prevent disputes-especially between geographically closer states-from being escalated into military conflicts. However, the positive relation between bilateral trade interdependence and the probability of military conflict in the upper range of bilateral distance is puzzling. This may reflect that the strong bilateral trade between distant states often comes from more asymmetric trade links, which is often related to exploitation and economic conflicts, leading to more military conflicts between them.

The estimation result in column (6) also confirms that the impact of global trade openness varies depending on the distance between countries. The estimated coefficient on the interactive term between global trade openness and distance $(-0.602$, s.e. $=0.21)$ is significantly negative, while 
the estimated coefficient on global trade openness, $(2.44$, s.e.=1.57), is positive but statistically insignificant. ${ }^{15}$ The strong peace-promotion effect of global trade openness for all country pairs regardless of their geographical distance contrasts the negative relation between bilateral trade dependence and peace for the group of geographically distant country pairs.

The significantly negative interactive term between global trade openness and distance indicates that the peace-promotion impact of global trade openness is higher for geographically distant countries. An increase in global trade openness likely decreases the probability of conflict less for proximate countries than for distant countries. This may reflect that greater global trade integration can be more helpful to promote peace for dyads of distant countries which likely participate in global conflict, rather than cross-border conflict.

Column (7) of Table 4 introduces the interaction terms of the bilateral and global trade integration variables with contiguity by substituting for their interaction terms with bilateral distance. The estimated coefficient on bilateral trade interdependence, $(29.34$, s.e. $=6.05)$ is significantly positive and the estimated coefficient on the interactive term between bilateral trade dependence and contiguity $(-47.65$, s.e. $=7.85)$ is significantly negative.

Hence, the overall effect of bilateral trade dependence on the probability of military conflict hinges on contiguity. The peace-promotion effect of bilateral trade dependence appears to be significantly higher for contiguous countries. But, the estimates indicate that the relation between bilateral trade dependence and the probability of military conflict can be positive in non-contiguous countries, which is consistent with the result in column (6).

On the other hand, the estimated coefficient on the interaction term between contiguity and global trade openness $(1.69$, s.e. $=0.64)$ is positive and significant. The estimated coefficient on global trade openness $(-2.78$, s.e. $=0.52)$, is significantly negative. Hence, the two estimated coefficients imply that the overall marginal effect of global trade openness on the probability of military conflict is always negative for countries regardless of contiguity between them. Greater global trade integration can help to promote peace for all dyads, which is also consistent with the result in column (6).

Column (8) presents the estimation result of the specification in which all four interactive terms are included. In this specification, the estimated coefficients on bilateral trade interdependence, $(-29.05$, s.e. $=36.61)$ and global trade openness $(0.51$, s.e. $=2.21)$ become statistically insignificant. For the two interactive terms with bilateral trade dependence, only the interactive term between bilateral trade dependence and contiguity $(-34.37$, s.e. $=10.01)$ is negative and highly significant. Hence, the estimated result confirms that the overall impact of bilateral and global trade openness vary depending on the distance between countries.

\subsection{Robustness of the Results}

The robustness of the basic results of Table 4-about the effect of bilateral and global trade dependence on conflict-is checked. Table 5 considers other possible determinants of military interstate conflict, many of which have been proposed in previous studies. These additional variables are added to the basic specification for the MID in column (5) of Table 4.

The two point estimates for global trade and its interaction terms imply that the overall marginal effect of global trade openness on the probability of military conflict is negative for almost entire range of the sample. Only for the countries of which bilateral distance ranges below 4.05 , which is less than $0.05 \%$ of the dyads in the sample, the marginal impact of global trade openness can be positive. 
First, we control the possible spillover effects of military conflicts. The existence of other conflicts at the same time can influence both an occurrence of a bilateral military conflict and bilateral trade flows between a dyad of states. Column (1) of Table 4 includes as an additional explanatory variable the total number of MID that the countries of the dyad are involved in. It shows that the estimated coefficients on all trade variables remain significant.

Column (2) includes a dummy for all country pairs for which there was no trade between them to control whether or not the two countries have an economic relationship. The zero-trade dummy variable becomes significantly negative, but does not have any significant impact on other estimated coefficients.

Column (3) adds an index for common language and column (4) adds a dummy variable for country pairs with a history of colonialization to control for cultural and/or historical factors that might affect the occurrence of conflicts. It is found that these additional variables tend to make the bilateral trade interdependence variable statistically insignificant. This may be due partly from the significant correlation between these additional variables and bilateral trade.

Column (5) adds the measure of political proximity between two countries as a possible determinant of military conflicts. It is the "affinity of nations"' index (Gartzke, 2000), which is constructed by using UN voting data. ${ }^{16}$ It is assumed that when the UN voting patterns of two nations are more alike, their political interests would be more similar. The index ranges from -1 (most dissimilar) to 1 (most similar). The variable appears significantly negative, indicating that countries that share similar political interests are less likely to engage in military conflicts.

Column (6) includes cubic splines of the number of peace years to further control for the potential "temporal dependence" problem. An occurrence of a military conflict not only can have an immediate impact on bilateral trade, but also can influence on the probability of military conflicts at any future moment. Beck et al.(1998) suggest to add cubic splines of the number of peace years, as well as the number of peace years variable, to correct for a temporal dependence bias. ${ }^{17}$ The estimation result shows that the inclusion of the cubic splines does not cause any significant change in the estimated coefficients.

The next three columns present the results with the interaction terms with bilateral distance (column 6) and with contiguity (column 7). The estimated coefficients on the interactive terms are statistically significant and the main results in the basic specifications in Table 4 still hold.

For our purposes, an important finding is that the role of bilateral and global trade integration on military conflict—often after interacting with geographical proximity between countries-is robust to the introduction of these additional variables.

In order to minimize the simultaneous correlation problem between trade variables and military disputes, columns (1)-(4) of Table 6 present estimation results with 3-year lagged trade integration variables. The main results are similar to those in Table 4. But, the 3-year lagged bilateral trade interdependence variable becomes insignificant in column (1) of Table 6.

\footnotetext{
16 We use data on UN roll-call votes on resolution in the United Nations General Assembly collected by Erik Voeten (http://www9.georgetown.edu/faculty/ev42/UNvoting.htm). Alesina and Dollar (2000) and Barro and Lee (2005) used the UN voting data to investigate the influence of the US and major powers on foreign-aid and IMF lending decisions.

17 The other solution is including dummy variable $K_{t}(t=1,2, \ldots)$ which is coded as 1 according to the length (t) of sequence of zeros that precede the current observations. This is exactly the same as including every lagged dependent variable.
} 
Also investigated were different trade integration measures, including the log of arithmetic averages, rather than geometric averages, of bilateral or global trade integration of the two countries. ${ }^{18}$ The estimation results of Columns (5)-(8) in Table 6 show that they are very similar to those in Tables 4 and 5.

\subsection{Instrument Variable Estimation}

The empirical investigation of the effects of trade integration on military conflicts encounters standard endogeneity problems. The causality can run in the opposite direction: military conflicts have a negative effect on trade (Glick and Taylor, 2006, Blomberg and Hess, 2006, and Martin et al. 2008). It is also plausible that the negative effects of trade may reflect any omitted dyadic characteristics that influence the probability of military conflicts. The logit estimates may not therefore reveal the true effect of trade integration on military conflicts. We have used lagged trade variables to reduce endogeneity of trade as an explanation of military conflicts to the certain extent.

In this section, we implement an instrument variable approach to control potential endogeneity problems. We use as instrument variables the Generalized System of Preference (GSP) scheme interacted with distance and an index of economic remoteness measure of dyads as suggested by Martin et al. (2008) and add one more instrument variable.

The Generalized System of Preference (GSP) scheme is tariff preferences granted by developed countries to developing countries. Romalis (2003) shows that GSP program increases Least Developed Countries' (LDC) trade significantly by facilitating LDC's access to markets of rich and distant developed countries. We choose European Union (EU) GSP schemes and multiply it by the geographical proximity from EU member countries to the recipients of the EU GSP program. We lag this variable by 4 years. GSP participation is expected to increase global trade openness while its relation to bilateral trade is ambiguous due to the distance multiplier.

The second instrumental variable is the measure of remoteness of dyads from the rest of world. This variable is routinely used in trade literature as an important determinant of bilateral trade flows (Anderson and van Wincoop, 2004, and Baier and Bergstrand, 2004). ${ }^{19}$ When constructing the remoteness variable, we exclude any third country $\mathrm{k}$ which had military conflicts with one of dyads at any moment in history. We also lag this variable by 2 years. An increase in remoteness of dyads is expected to increase bilateral trade of dyads, but decreases global trade.

The third instrumental variable is the number of trading countries of dyads (lagged by 2 years). This new variable is added to strengthen the validity of instrumental variable estimation. This variable is constructed by adding up the number of each country's trading partners whose trade flow is not missing and greater than zero. In counting the number of trading partners, we exclude any third country $\mathrm{k}$ which had military conflicts with one of dyads at any moment in history. If a country trades with a larger number of partners, its global trade integration is expected to be larger. On the contrary, an increase in total trading partners of dyads can have

18 To keep the zero observations when making the log transformation of bilateral trade dependence measure, we use log (1+x).

19 The remoteness of dyad $(i, j)$ is defined as $\ln \left(\sum_{k \neq i, j}^{N_{t}} \frac{\text { distance }_{i k}}{N_{t}-1}\right)+\ln \left(\sum_{k \neq i, j}^{N_{t}} \frac{\text { distance }_{j k}}{N_{t}-1}\right)$ This variable is time variant because new countries have generated almost every year during the period from 1950 to 2000. Alesina et al.(2000) show the number of countries in world has drastically increased from 1950 to 2000.(74 countries in 1946 to 192 in 2000). 
an ambiguous effect on bilateral trade: it can divert the bilateral trade between two countries to other global partners so that bilateral trade decreases, while an increase in the number of trading partners of dyads implies that dyads are integrated more with global markets and thus their overall trade volume increases.

Because there is no standard IV estimation methodology in the logit framework with clustered dyads, we follow one of solutions provided by Wooldridge (2001), which is to use an IV linear probability model with clustered errors. The logit model is non-linear, so we also use an IV probit model to check robustness of the instrumental variable approach and to reinforce the results.

Table 7 shows the first stage regression of IV estimation. Columns (1) and (2) show the instrumentation of GSP, remoteness and number of trading partners on bilateral trade interdependence and global trade openness respectively. As expected, GSP has a positive effect on global trade openness. Remoteness has a significantly positive effect on bilateral trade dependence and a significantly negative effect on global trade openness. The estimates of number of trading partners on bilateral trade and global trade integration are both significantly positive. Both F-test statistics on the joint-null effect of the three instruments are 14.25 (on bilateral dependence) and 35.07 (on global trade openness) and exceed 10, the threshold number recommended by Staiger and Stock (1997). Thus, we can reject the hypothesis that the IV equation is weakly identified and confirm that the instruments are theoretically and statistically powerful.

Table 8 presents the results of second stage instrumental variable (IV) regressions. Column (1) of Table 8 show the results of IV linear probability model regressions and column (2) display the result of IV probit regressions using the clustered bootstrap method. ${ }^{20}$ The results are broadly consistent with the logit estimation results. Column (1) shows that an increase in both bilateral trade interdependence and global trade openness significantly promotes peace respectively at $5 \%$ and $1 \%$ critical levels. Column (2) also shows global trade integration reduces the probability of conflicts and other coefficients are qualitatively same as column (1). Hence, the negative effects of trade integration on military conflicts in the logit estimation do not reflect the reverse causality that runs from military conflicts to trade or the influence of any omitted characteristics.

Columns (3) and (4) add the interactive terms of bilateral and global trade openness with the geographical proximity variables. The IV estimation results broadly support the basic result of logit estimation by confirming that the coefficients of bilateral and global trade openness depending on the geographical proximity of countries are also qualitatively the same as the coefficients of logit model.

We find no evidence of an over-identification problem. The joint-null hypothesis for SarganHansen's over-identification test, which implies that instruments are uncorrelated with the error

20 IV probit estimation with clustered standard errors is not feasible in this case. Therefore, we use clustered bootstrap method, which constructs a number of resamples of the observed data by dyads(clustered pairs) and then estimates by IV probit method. The bootstrap method is useful in reducing a finite sample bias. But it is also used to get statistical inference of the model when parametric inference is impossible or requires complicated formulas for calculating standard errors (Horowitz 2001). 
term, cannot be rejected. The test statistics is 1.449 (p-value is 0.221 ) in case of specification of column (1) supports the exogeneity hypothesis of our instruments. ${ }^{21}$

\section{The Impact of Military Interstate Disputes on Trade Integration}

We assess the effect of trade integration on military conflicts and find that both bilateral and global trade integration contribute to peace. However, the reverse causal effect from military conflicts to trade integration remains an issue. A number of studies have assessed the effect of military conflicts on bilateral trade flows (Glick and Taylor, 2006, Blomberg and Hess, 2006, and Martin et al. 2008), whereas how much military conflicts between countries affect multilateral trade of the states concerned has not been investigated to the same extent. This section analyzes the effect of military conflicts on bilateral and global trade integration. We adopt the gravity model analysis to evaluate the trade effects of military conflicts (Anderson and van Wincoop 2003). The extended gravity model of bilateral trade takes the following form.

$$
\text { Trade Integration }{ }_{i j t}=\alpha+\sum_{k=1}^{5} \beta_{k} M_{i j, t-k}+\gamma X_{i j t}+\delta \times \text { Year }_{t}+u_{i j t}
$$

where the dependent variable is a measure of bilateral trade interdependence of a dyad of states $i$ and $j . M I D_{t-k}(k=0, \ldots .5)$ are military conflict variables including from contemporaneous conflict to 5-year lagged conflict, and $\mathrm{Year}_{t}$ denotes a set of binary variables which are unity in the specific year $t$. $X_{i j t}$ includes other control variables shown in the gravity equation. They include square root of product real GDP of dyads, square root of product of real GDP per capita, ${ }^{22}$ geographical proximity (distance, contiguity) of dyads, common language, and colonial relationship dummy variables such as common colonizers and existence of a colonial relationship. The specification also has a Regional Trade Agreement (RTA) dummy, a binary variable which is unity if $i$ and $j$ belong to the same RTA, and a GATT membership dummy as coded 1 if two countries are both GATT signatories at observation year( $t$. GSP dummy is also added. Lastly, we add the remoteness, and the number of trading partners, which were used as instruments for bilateral trade in the previous section.

21 Other over-identification test also cannot reject the null hypothesis. The $\mathrm{J}$ statistics of Sargan-Hansen test are $2.063(\mathrm{p}-$ value $=0.356$ ) in column (3) and 4.886(p-value=0.1) in column (4).

22 A more detailed discussion of the gravity model is in Anderson and van Wincoop (2003).

From equation (13) in Anderson and van Wincoop(2003), $x_{i j}=\frac{Y_{i} Y_{j}}{Y_{w}}\left(\frac{t_{i j}}{P_{i} P_{j}}\right)^{1-\sigma}=\frac{Y_{i} Y_{j}}{Y_{w}} C_{i j}$. Assume 'multilateral resistance $(P)$ ' and 'bilateral resistance $(t)$ ' are symmetric between $i$ and j $\left(C_{i j}=C_{j i}\right)$ and set $C_{i j}$ constant as 1 .

Bilateral trade flow is defined as $T_{i j}=x_{i j}+x_{j i}=2\left(\frac{Y_{i} Y_{j}}{Y_{w}}\right)=T_{j i}$. Our bilateral trade dependence measure is the geometric average of bilateral trade flow of GDP of $\mathrm{i}$ and $\mathrm{j}$, which is $\sqrt{\frac{T_{i j}}{Y_{i}}} \sqrt{\frac{T_{j i}}{Y_{j}}}=\frac{T_{i j}}{\sqrt{Y_{i} Y_{j}}}$.

Therefore, we derive $\frac{T_{i j}}{\sqrt{Y_{i} Y_{j}}}=2\left(\frac{\sqrt{Y_{i} Y_{j}}}{Y_{w}}\right)$ which shows why we include square root of product of GDP of $\mathrm{i}$ and $\mathrm{j}$. 
Table 9 shows the estimation results of regressing bilateral trade interdependence on military conflicts and other controls. We apply two different estimation techniques. ${ }^{23}$ Column (1) is estimated by pooled OLS allowing for clustering of common country-pair error terms over time and column (2) is the result by the fixed-effects estimation controlling for unobserved countrypair fixed effects. Both columns (1) and (2) display very similar results. First of all, the results confirm that the significant negative effects of military conflicts on bilateral trade integration. In column (1), the coefficients of all military conflict variables are significantly negative. The estimates imply that during a bilateral military conflict, bilateral trade integration declines by 0.007 over the next 5 years, which much bigger than the predicted mean of bilateral trade dependence, $0.002 .{ }^{24}$ As a matter of fact, $94 \%$ of dyads have lower bilateral trade dependence than 0.007 so that these country dyads would lose all trade between them if a military conflict occurred and lasted over 5 years. In column (2), with the adoption of the fixed-effects estimation, the effects of military conflicts on bilateral trade become smaller, but most of the estimated coefficients are still negative and statistically significant.

We also find that the conventional variables behave very much the same way as the model predicts, and the estimated coefficients are statistically significant. The estimated coefficients on the RTA membership dummy in both columns (1) and (2) are positive and statistically significant. The estimated coefficient on the GATT membership dummy is also positive, but statistically significant only in the fixed-effect estimation.

We slightly change the specification of gravity model in (2) in order to analyze the effect of military conflicts on global trade integration. The dependent variable is a measure of global trade integration of dyads. The specification follows the basic gravity equation with contemporaneous and lagged military conflicts. For the other control variables, we alter some bilateral variables to have more direct relationship with global trade pattern of dyads.

For example, we include square root of product of real GDP (and GDP per capita) with all other trading partners of $\mathrm{i}$ and $\mathrm{j}\left(\sqrt{\sum_{k \neq i, j}^{N} Y_{k, t}} \times \sqrt{\sum_{m \neq i, j}^{N} Y_{m, t}}\right) \cdot{ }^{25}$ The GATT dummy variable is coded as 1 when only one country in any dyad is a GATT member. This is because a country of any dyad that joins GATT is likely to trade more with other GATT members. Thus, we can expect this dummy variable to be positively related to global trade integration. We also include the sum of the number of countries using a common language with $i$ and $j$. This variable controls cultural proximity of each country in a dyad with other countries, which can be related to the global trade

23 We also implement tobit estimation method to control zero bilateral trade (left-censored) and get qualitatively same results. See Silva and Tenreyro (2006) and Helpman et al.(2008) more about zero trade problem.

$24 \frac{\partial E(y \mid x) / E(y \mid x)}{\partial x}=-3.5$ (semi-elasticity). Therefore, bilateral trade integration decreases by $350 \%$ when military conflict occurred and lasted over 5 years. The effect of military conflicts on bilateral trade dependence is huge.

25 Our global trade integration measure is $\sqrt{\frac{T_{i, \text { rest }}}{Y_{i}}} \sqrt{\frac{T_{j, \text { rest }}}{Y_{j}}}$, where $T_{i, \text { rest }}=2\left(\frac{Y_{i} Y_{\text {rest }(i)}}{Y_{w}}\right)$ is multilateral trade flows between $i$ and rest of the world. We also derive $\sqrt{\frac{T_{i, \text { rest }}}{Y_{i}}} \sqrt{\frac{T_{j, \text { rest }}}{Y_{j}}}=2\left(\frac{\sqrt{Y_{\text {rest }(i)} Y_{\text {rest }(j)}}}{Y_{w}}\right)$ which shows the reason we include square root of all other trading partners GDP of $i$ and $j$. 
cost of each country in the dyad. The number of other conflicts in $t$ is included to control the externality of conflicts among countries that could affect a dyad's global trade integration. The specification also includes each country's remoteness, and the number of trading partners, and the EU GSP with distance variables that were used as instruments for global trade as outlined in the previous section.

Table 10 displays the estimation results of global trade integration on military conflicts and other controls. We find that military conflicts have a negative effect on global trade integration. In column (1), the estimated coefficients of all military conflicts are significantly negative. This implies that a bilateral military conflict of a dyad reduces global (multilateral) trade integration by 0.16 over the ensuing 5 years, which means global trade integration decreases by $30 \%{ }^{26}$ if a military conflict between countries occurred and lasted over 5 years. In the fixed-effect estimation of column (2), the estimated coefficients on one and two lagged military conflicts are statistically significant individually. The coefficients of other military conflict variables are negative but become statistically insignificant. The estimation results of other control variables confirm our predictions. The estimated coefficients on the square root of real GDP or GDP per capita of trading-partner variables are statistically significant. The estimated coefficients on the one GATT membership dummy are also positive and statistically significant-a country's participation in GATT makes their trade increase with other GATT members while decreasing trade with non-GATT members. Lastly, the coefficients on the number of countries with common languages are significantly positive, which coincide with the conventional positive effect of common language on trade.

\section{Concluding Remarks}

The empirical analysis shows that an increase in bilateral trade interdependence and global trade openness significantly reduces the probability of military conflict between countries. Our empirical results are robust when controlling for the simultaneous determination of trade and peace.

Our results also support that the peace-promotion effect of trade varies depending on the geographical proximity between countries. Greater bilateral trade interdependence appears to bring about a considerably larger peace-promotion effect for neighboring countries. In contrast, greater global trade openness has a more significantly positive effect on peace for distant countries than it does on neighboring ones.

Overall, our results consistently show that trade integration has an important effect on conflict between states. A recent seminal paper in global trade and conflict (Martin et al, 2008) argues that globalization (increase in multilateral trade) can increase the probability of military conflict by reducing the bilateral dependence to any given country. Our empirical findings largely refute this argument. It is evident that greater global trade openness is helpful in promoting peace. Future research is needed to define the exact channels through which global trade openness promotes interstate peace.

\footnotetext{
26 $\frac{\partial E(y \mid x)}{\partial x}=-0.16$ and $E(y \mid x)=0.48$ (the predicted mean of global trade integration between countries). Thus, $\frac{\partial E(y \mid x) / E(y \mid x)}{\partial x}=-0.3$ (semi-elasticity)
} 
Our findings suggest that trade integration not merely results in economic gains but can bring about significant political gains as well-such as a peace dividend between trading partners. It also explains why regional or global economic integration are often initiated to satisfy political and security motives. For example, the raison d'etre behind the formation of the European Union following the Second World War was the desire for peace-particularly between France and Germany. Further research on quantitative assessments of peace dividends resulting from economic integration would be of great interest. 


\section{References:}

Alesina, A. and D. Dollar. 2000. Who Gives Foreign Aid to Whom and Why? Journal of Economic Growth. 5. pp.33-64.

Alesina, A., E. Spolaore and R. Wacziarg. 2000. Economic Integration and Political Disintegration. American Economic Review. 90(5). pp. 1276-1296.

Anderson, J. and E. van Wincoop. 2003. Gravity with Gravitas: A Solution to the Border Puzzle. American Economic Review. 93. pp. 170-192.

Anderson, J. and E. van Wincoop. 2004. Trade Costs. Journal of Economic Literature. XLII. pp. 691-751.

Baier, S. and J. Bergstrand. 2004. Economic Determinants of Free Trade Agreements. Journal of International Economics. 64. pp. 29-63.

Barbieri, K. 1996. Economic Interdependence: A Path to Peace or a Source of Interstate Conflict? Journal of Peace Research. 33(1). pp. 29-49.

Barbieri, K. and G. Schneider. 1999. Globalization and Peace: Assessing New Directions in the Study of Trade and Conflict. Journal of Peace Research. 36(4). Special Issue on Trade and Conflict. pp. 387-404.

Barrett, D. B. 1982. World Christian Encyclopedia. First Edition. Oxford, UK: Oxford University Press.

Barrett, D. B., G. Kurian and T. Johnson. 2001. World Christian Encyclopedia. Second edition. Oxford, UK: Oxford University Press.

Barro, R. 2006. Rare Disasters and Asset Markets in the Twentieth Century. Quarterly Journal of Economics. 121. pp. 823-86.

Barro, R. and J-W. Lee. 2005. IMF Programs: Who Is Chosen and What Are the Effects. Journal of Monetary Economics. 52(7). pp. 1245-1269.

Barro, R. and R. McCleary. 2005. Which Countries Have State Religions? Quarterly Journal of Economics. pp. 1331-1370.

Beck, N., J. Katz and R. Tucker. 1998. Taking Time Seriously: Time-Series-Cross-Section Analysis with a Binary Dependent Variable. American Journal of Political Science. 42. pp. 1260-1288.

Blomberg, S. and G. D. Hess. 2006. How Much Does Violence Tax Trade? Review of Economics and Statistics. 88(4). pp. 599-612.

Bremer, S. A. 1993. Democracy and Militarized Interstate Conflict. 1816-1965. International Interactions. 17(3). pp. 231-249.

Chiozza, G. 2002. Is There a Clash of Civilizations? Evidence from Patterns of International Conflict Involvement, 1946-97. Journal of Peace Research. 39. pp. 711-734. 
Cameron, A. C., J. Gelbach and D. Miller. 2006. Robust Inference with Multi-Way Clustering. NBER Technical Working Paper No. 32.

Davis, D. and D. Weinstein. 2002. Bones, Bombs, and Break Points: The Geography of Economic Activity. American Economic Review. 92(5). pp. 1269-1289.

Dixon, W. J. 1993. Democracy and the Management of International Conflict. Journal of Conflict Resolution. pp. 37-42.

Domke, W. K. 1988. War and the Changing Global System. New Haven, CT: Yale University Press.

Dos Santos, T. 1970. The Structure of Dependence. American Economic Review. 60(2). pp. 231-236.

Emmanuel, A. 1972. Unequal Exchange: A Study of the Imperialism of Trade. New York \& London: Monthly Review Press.

Fairhead, J. 2000. The Conflict over Natural and Environmental Resources. In Wayne, E.W., F. Stewart and R. Vayrynen, eds. The Origins of Humanitarian Emergencies: War and Displacement in Developing Countries. Oxford: Oxford University Press.

Feenstra, Robert. 2004. Advanced International Trade: Theory and Evidence. NJ: Princeton University Press.

Gartzke, E. 2000. Preferences and the Democratic Peace. International Studies Quarterly. 44(2). pp. 191-210.

Gartzke, E. and Q. Li. 2003. Measure for Measure: Concept Operationalization and the Trade Interdependence-Conflict Debate. Journal of Peace Research. 40(5). pp. 553-571.

Gasiorowski, M. J. 1986. Economic Interdependence and International Conflict: Some CrossNational Evidence. International Studies Quarterly. 30(1). pp. 23-38.

Gleditsch, K. S. 2002. Expanded Trade and GDP. Journal of Conflict Resolution. 46(5). pp. 712724.

Glick R. and A. Taylor. 2005. Collateral Damage: Trade Disruption and the Economic Impact of War. NBER Working Paper No. 11565.

Greene, W. 2002. Econometric Analysis. Fifth Edition. Prentice Hall.

Guiso, L., P. Sapienza and L. Zingales. 2003. People's Opium? Religion and Economic Attitudes. Journal of Monetary Economics. 50(1). pp. 225-282.

Helpman, E., M. Melitz and Y. Rubinstein. 2008. Estimating Trade Flows: Trading Partners and Trading Volumes. Quarterly Journal of Economics. 123:2. pp. 441-487.

Henderson, E. 1998. The Democratic Peace Through the Lens of Culture. 1820-1989. International Studies Quarterly. 42(3). pp. 461-484. 
Hess, G. and A. Orphanides. 1995. War Politics: An Economic, Rational-Voter Framework. American Economic Review. 85(4). pp. 828-846.

Hess, G. and A. Orphanides. 2001. War and Democracy. Journal of Political Economy. 109(4). pp. $776-810$.

Horowitz, J. 2001. The Bootstrap in Econometrics. Chapter 52 in Heckman, J.J. and E.E. Leamer, eds. Handbook of Econometrics. Vol. 5. Amsterdam: J.J. Elsevier Science B.V.

Huntington, S. P. 1996. The Clash of Civilizations and the Remaking of World Order. New York: Simon \& Schuster.

Huntington, S. P. 2000. Try Again: A Reply to Russett, Oneal and Cox. Journal of Peace Research. 37(5). pp. 609-610.

Keohane, O. and J. S. Nye. 1973. World Politics and the International Economic System. In Bergsten, C. F., ed. The Future of the International Economic Order: An Agenda for Research. Lexington, MA: DC Heath.

Klare, M. T. 2001. Resource Wars: the New Landscape of Global Conflict. New York: Metropolitan Books.

Laustsen, C. B. and O. Wæver. 2000. In Defense of Religion: Sacred Referent Objects for Securitization. Millennium. 29(3). pp. 705-739.

Le Billion, P. 2001. The Political Ecology of War: Natural Resources and Armed Conflicts. Political Geography. 20. pp. 561-584.

Maoz, Z. 2005. Dyadic MID Dataset(version 2.0). Available: http://psfaculty.ucdavis. ucdavis. edu/zmaoz/dyadmid.html

Martin, P., T. Mayer and M. Thoenig. 2008. Make Trade not War? Review of Economic Studies. 75. pp. 865-900.

Mcdonald, P. 2004. Peace through Trade or Free Trade? Journal of Conflict Resolution. 48. pp. 547-572.

Oneal, J. and B. Russett. 1997. The Classical Liberals Were Right: Democracy, Interdependence, and Conflict, 1950-85. International Studies Quarterly. 41(2). pp. 267294.

Oneal J. and B. Russett. 1999. Assessing the Liberal Peace with Alternative Specifications: Trade Still Reduces Conflict. Journal of Peace Research. 36(4). Special Issue on Trade and Conflict. pp. 423-442.

Oneal J., F. Oneal, Z. Maoz and B. Russett. 1996. The Liberal Peace: Economic Interdependence, Democracy, and International Conflict, 1950-85. Journal of Peace Research. 33(1). pp.11-28.

Polachek, S. 1980. Conflict and Trade. Journal of Conflict Resolution. 24(1). pp. 57-78. 
Polachek, S., J. Robst and Y-C. Chang. 1999. Liberalism and Interdependence: Extending the Trade-Conflict Model. Journal of Peace Research. 36(4). Special Issue on Trade and Conflict. pp. 405-422.

Romalis, J. 2003. Would Rich Country Trade Preferences Help Poor Countries Grow? Evidence From the Generalized System of Preferences. Chicago GSB. Mimeo.

Russett, B., J. Oneal and M. Cox. 2000. Clash of Civilizations, or Realism and Liberalism Déjà Vu? Some Evidence. Journal of Peace Research. 37(5). pp. 583-608.

Schneider, G., K. Barbieri and N. P. Gleditsch. 2003. Does Globalization Contribute to Peace? A Critical Survey of the Theoretical and Statistical Literature. In Schneider, G., K. Barbieri and N. P. Gleditsch, eds. Globalization and Armed Conflict. Lanham, MD: Rowman \& Littlefield.

Signorino, C. and J. Ritter. 1999. Tau-b or Not Tau-b: Measuring the Similarity of Foreign Policy Positions. International Studies Quarterly. 43(1). pp.115-144.

Silva, J. M., C. Santos and S. Tenreyro. 2006. The Log of Gravity. Review of Economics and Statistics. 88. pp. 641-658.

Staiger, D. and J. Stock. 1997. Instrumental Variables Regression with Weak Instruments. Econometrica. 65(3). pp. 557-586.

Wallerstein, I. 1974. The Rise and Future Demise of the World Capitalist System: Concepts for Comparative Analysis. Comparative Studies in Society and History. 16(4). pp. 387-415.

Wooldridge, J. 2001. Econometric Analysis of Cross Section and Panel Data. Second Edition. Cambridge, MA: The MIT Press. 

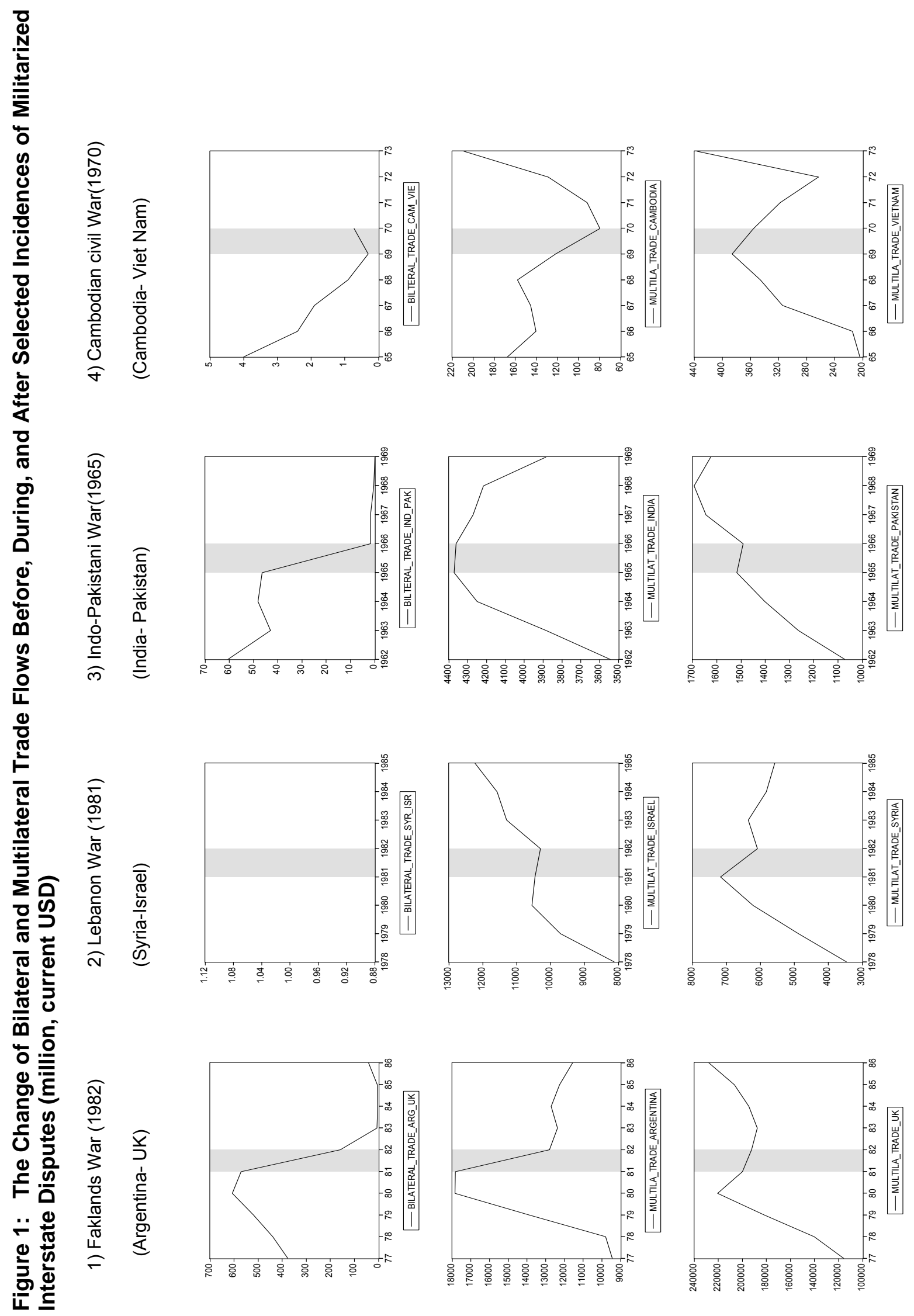

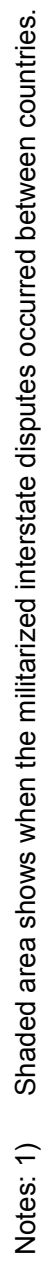


Table 1: Militarized Interstate Disputes, 1950-2000

\begin{tabular}{|c|c|c|c|c|c|}
\hline & & \multicolumn{2}{|c|}{ Full Sample } & \multicolumn{2}{|c|}{ Regression Sample } \\
\hline & & $\begin{array}{l}\text { Pair-ye } \\
\text { Observat }\end{array}$ & $\%$ & $\begin{array}{r}\text { Pair-ye } \\
\text { Observat }\end{array}$ & $\%$ \\
\hline \multicolumn{2}{|c|}{ All dyads } & \multicolumn{2}{|c|}{572246} & \multicolumn{2}{|c|}{290040} \\
\hline \multicolumn{2}{|c|}{ Non-Fighting dyads } & \multicolumn{2}{|c|}{569841} & \multicolumn{2}{|c|}{288447} \\
\hline Fighting & AID) dyads & 2405 & 100.00 & 1593 & 100.00 \\
\hline & 2 (Threat to use force) & 119 & 4.95 & 81 & 5.08 \\
\hline \multirow{3}{*}{$\begin{array}{l}\text { Hostility } \\
\text { level }\end{array}$} & 3 (Display of Force) & 528 & 21.95 & 420 & 26.37 \\
\hline & 4 (Use of force) & 1494 & 62.12 & 1017 & 63.84 \\
\hline & 5 (War) & 264 & 10.98 & 75 & 4.71 \\
\hline
\end{tabular}

Source: Constructed from the Database of the "Correlates Of War (COW)" project with Maoz correction, Zeev Maoz (2005). Dyadic MID Dataset (version 2.0): http://psfaculty.ucdavis.edu/zmaoz/dyadmid.html

Table 2: Top 15 Countries That are Most Frequently Involved in the Militarized Interstate Disputes (MID), 1950-2000

\begin{tabular}{|c|c|c|c|c|c|c|c|}
\hline No & Country & \# of MIDs & (War) & (Use of Force) & $\begin{array}{c}3 \\
\text { (Display } \\
\text { of Force) }\end{array}$ & $\begin{array}{c}2 \\
\text { (Threats) }\end{array}$ & $\begin{array}{c}\text { The country's } \\
\text { participation in } \\
\text { total MID events } \\
(\%)\end{array}$ \\
\hline 1 & United States & 160 & 3 & 55 & 92 & 10 & 10.97 \\
\hline 2 & USSR/Russia & 119 & 1 & 61 & 47 & 10 & 8.16 \\
\hline 3 & China, People's Rep. of & 113 & 4 & 73 & 28 & 8 & 7.75 \\
\hline 4 & Iran & 105 & 1 & 83 & 18 & 3 & 7.20 \\
\hline 5 & Israel & 95 & 5 & 69 & 18 & 3 & 6.52 \\
\hline 6 & Iraq & 84 & 3 & 69 & 11 & 1 & 5.76 \\
\hline 7 & India & 72 & 3 & 44 & 19 & 6 & 4.94 \\
\hline 8 & Syria & 68 & 4 & 51 & 12 & 1 & 4.66 \\
\hline 9 & Turkey & 61 & 2 & 33 & 17 & 9 & 4.18 \\
\hline 10 & Egypt & 60 & 5 & 33 & 19 & 3 & 4.12 \\
\hline 11 & United Kingdom & 57 & 4 & 23 & 25 & 5 & 3.91 \\
\hline 12 & Thailand & 46 & 2 & 27 & 14 & 3 & 3.16 \\
\hline 13 & Pakistan & 45 & 2 & 35 & 5 & 3 & 3.09 \\
\hline 13 & Korea, Republic of & 45 & 2 & 36 & 6 & 1 & 3.09 \\
\hline 15 & France & 41 & 3 & 22 & 13 & 3 & 2.81 \\
\hline
\end{tabular}




\begin{tabular}{|c|c|c|c|c|c|c|c|}
\hline \multirow[b]{2}{*}{ Variable } & \multicolumn{3}{|c|}{$\begin{array}{c}\text { (1) All } \\
(\mathrm{N}=290,040)\end{array}$} & \multicolumn{2}{|c|}{$\begin{array}{l}\text { (2) Conflict } \\
(\mathrm{N}=1593)\end{array}$} & \multicolumn{2}{|c|}{$\begin{array}{l}\text { (3) No-Conflict } \\
\text { (N=288,447) }\end{array}$} \\
\hline & Mean & Median & $\begin{array}{l}\text { Std. } \\
\text { Dev. }\end{array}$ & Mean & $\begin{array}{l}\text { Std. } \\
\text { Dev }\end{array}$ & Mean & $\begin{array}{l}\text { Std. } \\
\text { Dev. }\end{array}$ \\
\hline Military Interstate Disputes & 0.0055 & 0 & 0.0739 & 1 & 0 & 0 & 0 \\
\hline $\begin{array}{l}\text { Bilateral trade dependence } \\
(2 \text { years lagged })\end{array}$ & 0.002 & 0.00029 & 0.0082 & 0.0056 & 0.0134 & 0.0019 & 0.0081 \\
\hline $\begin{array}{l}\text { Global trade openness } \\
(2 \text { years lagged) }\end{array}$ & 0.4880 & 0.4219 & 0.3798 & 0.3338 & 0.2667 & 0.4888 & 0.3801 \\
\hline Contiguity & 0.0377 & 0 & 0.1904 & 0.5895 & 0.4921 & 0.0346 & 0.1828 \\
\hline Distance (log) & 8.6172 & 8.8794 & 0.8238 & 7.3595 & 1.2418 & 8.6241 & 0.8155 \\
\hline $\begin{array}{l}\text { Log difference of GDP } \\
\text { (2 years lagged) }\end{array}$ & 2.5135 & 2.1633 & 1.8437 & 2.1562 & 1.6900 & 2.5154 & 1.8444 \\
\hline Major powers dummy & 0.0961 & 0 & 0.2948 & 0.3522 & 0.4778 & 0.0947 & 0.2928 \\
\hline $\begin{array}{l}\text { Joint democracy index } \\
(2 \text { years lagged })\end{array}$ & 0.3088 & 0.15 & 0.3313 & 0.2014 & 0.2531 & 0.3094 & 0.3316 \\
\hline $\begin{array}{l}\text { Alliance } \\
\text { (2 years lagged) }\end{array}$ & 0.0919 & 0 & 0.2889 & 0.2555 & 0.4363 & 0.0910 & 0.2877 \\
\hline $\begin{array}{l}\text { Religious Similarity } \\
\text { ( } 2 \text { years lagged) }\end{array}$ & -0.2316 & -0.349 & 0.5662 & 0.0356 & 0.6123 & -0.2331 & 0.5656 \\
\hline Oil exporters dummy & 0.1603 & 0 & 0.3668 & 0.2140 & 0.4101 & 0.1602 & 0.3667 \\
\hline Number of Peace years & 22.2887 & 22 & 13.0996 & 6.0891 & 10.7993 & 22.3782 & 13.0556 \\
\hline
\end{tabular}

Note: See the text for an explanation of variables. 
Table 4: Determinants of Militarized Interstate Disputes

\begin{tabular}{|c|c|c|c|c|c|c|c|c|}
\hline & (1) & (2) & (3) & (4) & (5) & (6) & (7) & (8) \\
\hline \multirow{2}{*}{$\begin{array}{l}\text { Bilateral trade } \\
\text { dependence }(\mathrm{t}-2)\end{array}$} & $-18.643^{\star *}$ & & $-15.771^{* *}$ & -2.896 & $-8.495^{\star}$ & $-122.479^{\star * *}$ & $29.347^{* * *}$ & -29.049 \\
\hline & [7.959] & & [7.504] & [4.364] & [5.063] & [25.769] & [6.045] & [36.611] \\
\hline \multirow{2}{*}{$\begin{array}{l}\text { Global trade } \\
\text { Openness (t-2) }\end{array}$} & & $-2.037^{\star * *}$ & $-1.933^{\star * *}$ & 0.216 & $-1.836^{* * *}$ & 2.439 & $-2.778^{* * *}$ & 0.511 \\
\hline & & [0.463] & {$[0.457]$} & {$[0.178]$} & {$[0.370]$} & {$[1.567]$} & {$[0.521]$} & {$[2.236]$} \\
\hline \multirow{2}{*}{ Contiguity } & $2.990^{* * *}$ & $2.748^{\star \star \star}$ & $2.802^{\star * *}$ & & $2.112^{\star \star \star}$ & $2.081^{* * *}$ & $1.822^{\star \star *}$ & $1.972^{* \star *}$ \\
\hline & [0.242] & [0.225] & {$[0.227]$} & & {$[0.184]$} & [0.183] & {$[0.273]$} & {$[0.306]$} \\
\hline \multirow{2}{*}{ Distance(log) } & $-0.517^{* * *}$ & $-0.547^{\star \star *}$ & $-0.574^{* * *}$ & & $-0.475^{\star * *}$ & $-0.310^{\star \star *}$ & $-0.419^{\star \star \star}$ & $-0.314^{\star * *}$ \\
\hline & [0.084] & [0.084] & {$[0.087]$} & & [0.077] & [0.114] & {$[0.076]$} & [0.115] \\
\hline \multirow{2}{*}{$\begin{array}{l}\text { Log difference } \\
\text { of GDP (t-2) }\end{array}$} & $-0.123^{* * *}$ & $-0.116^{\star * *}$ & $-0.122^{\star * *}$ & $0.106^{* *}$ & $-0.115^{\star * *}$ & $-0.116^{* * *}$ & $-0.119^{* * *}$ & $-0.116^{\star * *}$ \\
\hline & [0.042] & [0.042] & [0.042] & [0.053] & [0.032] & [0.031] & [0.031] & [0.031] \\
\hline \multirow{2}{*}{ Major powers } & $2.213^{* * *}$ & $1.847^{* * *}$ & $1.950^{* * *}$ & & $1.852^{\star \star *}$ & $1.706^{* * *}$ & $1.749^{* * *}$ & $1.699^{* * *}$ \\
\hline & [0.201] & [0.209] & {$[0.203]$} & & {$[0.170]$} & {$[0.160]$} & {$[0.163]$} & {$[0.158]$} \\
\hline \multirow{2}{*}{$\begin{array}{l}\text { Joint democracy } \\
\text { Index (t-2) }\end{array}$} & $-1.268^{* * *}$ & $-1.366^{* * *}$ & $-1.157^{* * *}$ & $-0.875^{\star * *}$ & $-1.022^{* * *}$ & $-0.967^{* * *}$ & $-0.965^{\star * *}$ & $-0.952^{* * *}$ \\
\hline & [0.288] & [0.264] & [0.284] & [0.204] & [0.214] & {$[0.206]$} & [0.202] & [0.202] \\
\hline \multirow{2}{*}{ Alliance(t-2) } & -0.318 & $-0.341^{*}$ & -0.281 & -0.148 & 0.191 & 0.159 & 0.149 & 0.152 \\
\hline & {$[0.197]$} & [0.193] & [0.192] & [0.142] & [0.152] & {$[0.148]$} & {$[0.142]$} & [0.143] \\
\hline \multirow{2}{*}{$\begin{array}{l}\text { Religious Similarity } \\
(\mathrm{t}-2)\end{array}$} & -0.189 & -0.185 & -0.188 & $-2.507^{\star \star \star}$ & $-0.276^{* *}$ & $-0.287^{\star *}$ & $-0.291^{* *}$ & $-0.290^{* *}$ \\
\hline & [0.164] & [0.161] & [0.159] & [0.458] & [0.127] & [0.125] & {$[0.123]$} & [0.123] \\
\hline \multirow{2}{*}{$\begin{array}{l}\text { Oil exporters } \\
\text { dummy }\end{array}$} & 0.235 & $0.408^{* *}$ & $0.430^{* *}$ & & $0.456^{\star \star *}$ & $0.414^{* * *}$ & $0.400^{\star * *}$ & $0.405^{\star * *}$ \\
\hline & {$[0.171]$} & {$[0.172]$} & {$[0.172]$} & & {$[0.137]$} & [0.138] & {$[0.136]$} & {$[0.137]$} \\
\hline \multirow{2}{*}{$\begin{array}{l}\text { Number of Peace } \\
\text { years }\end{array}$} & & & & & $-0.135^{\star * *}$ & $-0.134^{* * *}$ & $-0.133^{\star * *}$ & $-0.133^{* * *}$ \\
\hline & & & & & {$[0.008]$} & [0.008] & [0.008] & {$[0.008]$} \\
\hline \multirow{2}{*}{$\begin{array}{l}\text { Distance }(\log ) \times \\
\text { Bilateral trade } \\
\text { dependence }\end{array}$} & & & & & & $16.950^{* * *}$ & & 7.078 \\
\hline & & & & & & [3.365] & & [4.375] \\
\hline Distance(log) & & & & & & $-0.602^{* * *}$ & & -0.409 \\
\hline × Global openness & & & & & & [0.214] & & {$[0.264]$} \\
\hline \multirow{2}{*}{$\begin{array}{l}\text { Contiguity } \times \\
\text { Bilateral trade } \\
\text { dependence }\end{array}$} & & & & & & & $\begin{array}{c}- \\
47.646^{* \star *}\end{array}$ & $-34.366^{\star \star \star}$ \\
\hline & & & & & & & [7.851] & [10.007] \\
\hline Contiguity & & & & & & & $1.692^{* * *}$ & 0.938 \\
\hline \multirow[t]{2}{*}{ × Global openness } & & & & & & & {$[0.639]$} & {$[0.808]$} \\
\hline & Logit & Logit & Logit & $\begin{array}{l}\text { Panel FE } \\
\text { Logit }\end{array}$ & Logit & Logit & Logit & Logit \\
\hline Observations & 290040 & 290040 & 290040 & 15589 & 290040 & 290040 & 290040 & 290040 \\
\hline Pseuo- $R^{2}$ & 0.281 & 0.285 & 0.289 & - & 0.38 & 0.385 & 0.384 & 0.389 \\
\hline
\end{tabular}

Note: The dependent variable is a binary variable for a militarized conflict between a dyad of states. All time-varying explanatory variables are lagged by two years. The summary statistics for all variables are shown in Table 3 . For columns (1) to (8) except column (4), the pooled logit estimation techniques were applied to 290,040 country pairs in total over the period from 1950 to 2000. The estimation allows for clustering of the error terms over time for country pairs. Column (4) uses conditional fixed effect logit estimation method. Clustered robust standard errors of the estimated coefficients are reported in bracket. Intercept and year dummy variables are included (not reported). ${ }^{* * *},{ }^{* *}$ and ${ }^{*}$ indicate that the estimated coefficients are statistically significant at $1 \%, 5 \%$, and $10 \%$ respectively. 
Table 5: Robustness Check I (Inclusion of other variables)

\begin{tabular}{|c|c|c|c|c|c|c|c|c|}
\hline & (1) & (2) & (3) & (4) & (5) & (6) & (7) & (8) \\
\hline $\begin{array}{l}\text { Bilateral trade } \\
\text { dependence }(\mathrm{t}-2)\end{array}$ & $\begin{array}{l}-8.495^{*} \\
{[5.063]}\end{array}$ & $\begin{array}{l}-9.562^{*} \\
{[5.133]}\end{array}$ & $\begin{array}{l}-8.152 \\
{[5.522]}\end{array}$ & $\begin{array}{l}-7.192 \\
{[5.108]}\end{array}$ & $\begin{array}{l}-7.279 \\
{[5.282]}\end{array}$ & $\begin{array}{l}-4.558 \\
{[4.936]}\end{array}$ & $\begin{array}{c}-92.092^{* * *} \\
{[25.334]}\end{array}$ & $\begin{array}{c}25.607^{* * *} \\
{[5.781]}\end{array}$ \\
\hline $\begin{array}{l}\text { Global trade } \\
\text { openness (t-2) }\end{array}$ & $\begin{array}{c}-1.836^{* * *} \\
{[0.370]}\end{array}$ & $\begin{array}{c}-1.863^{* * *} \\
{[0.371]}\end{array}$ & $\begin{array}{c}-1.946^{* * *} \\
{[0.420]}\end{array}$ & $\begin{array}{c}-1.907^{* * *} \\
{[0.416]}\end{array}$ & $\begin{array}{c}-1.653^{* * *} \\
{[0.390]}\end{array}$ & $\begin{array}{c}-1.010^{* * *} \\
{[0.357]}\end{array}$ & $\begin{array}{c}1.777 \\
{[1.187]}\end{array}$ & $\begin{array}{c}-1.801^{* * *} \\
{[0.546]}\end{array}$ \\
\hline Contiguity & $\begin{array}{c}2.112^{* * *} \\
{[0.184]}\end{array}$ & $\begin{array}{c}2.093^{* * *} \\
{[0.182]}\end{array}$ & $\begin{array}{c}2.105^{\star * *} \\
{[0.196]}\end{array}$ & $\begin{array}{c}2.076^{\star * *} \\
{[0.193]}\end{array}$ & $\begin{array}{c}2.202^{\star * *} \\
{[0.196]}\end{array}$ & $\begin{array}{c}1.906^{* * *} \\
{[0.197]}\end{array}$ & $\begin{array}{c}1.881^{* * *} \\
{[0.197]}\end{array}$ & $\begin{array}{c}1.691^{* * *} \\
{[0.265]}\end{array}$ \\
\hline Distance(Log) & $\begin{array}{c}-0.475^{\star \star \star} \\
{[0.077]}\end{array}$ & $\begin{array}{c}-0.465^{\star \star \star} \\
{[0.078]}\end{array}$ & $\begin{array}{c}-0.355^{\star * *} \\
{[0.067]}\end{array}$ & $\begin{array}{c}-0.367^{\star * \star} \\
{[0.064]}\end{array}$ & $\begin{array}{c}-0.468^{\star \star *} \\
{[0.072]}\end{array}$ & $\begin{array}{c}-0.384^{\star \star \star} \\
{[0.079]}\end{array}$ & $\begin{array}{c}-0.282^{\star * *} \\
{[0.101]}\end{array}$ & $\begin{array}{c}-0.355^{\star * *} \\
{[0.076]}\end{array}$ \\
\hline $\begin{array}{l}\text { Log difference } \\
\text { of GDP(t-2) }\end{array}$ & $\begin{array}{c}-0.115^{\star * *} \\
{[0.032]}\end{array}$ & $\begin{array}{c}-0.120^{* \star *} \\
{[0.032]}\end{array}$ & $\begin{array}{c}-0.120^{* * *} \\
{[0.035]}\end{array}$ & $\begin{array}{c}-0.123^{\star * *} \\
{[0.035]}\end{array}$ & $\begin{array}{c}-0.099^{* * *} \\
{[0.031]}\end{array}$ & $\begin{array}{c}-0.061^{* *} \\
{[0.030]}\end{array}$ & $\begin{array}{c}-0.060^{\star *} \\
{[0.030]}\end{array}$ & $\begin{array}{c}-0.065^{\star \star} \\
{[0.029]}\end{array}$ \\
\hline Major powers dummy & $\begin{array}{l}1.852^{\star * *} \\
{[0.170]}\end{array}$ & $\begin{array}{l}1.808^{* * \star} \\
{[0.167]}\end{array}$ & $\begin{array}{c}1.837^{* * *} \\
{[0.178]}\end{array}$ & $\begin{array}{l}1.779^{* * *} \\
{[0.183]}\end{array}$ & $\begin{array}{l}1.454^{* * *} \\
{[0.184]}\end{array}$ & $\begin{array}{l}1.304^{* * *} \\
{[0.169]}\end{array}$ & $\begin{array}{c}1.214^{* * *} \\
{[0.164]}\end{array}$ & $\begin{array}{c}1.234^{* * *} \\
{[0.164]}\end{array}$ \\
\hline $\begin{array}{l}\text { Joint democracy } \\
\text { index (t-2) }\end{array}$ & $\begin{array}{c}-1.022^{* * *} \\
{[0.214]}\end{array}$ & $\begin{array}{c}-1.065^{\star \star \star} \\
{[0.214]}\end{array}$ & $\begin{array}{c}-1.017^{* * *} \\
{[0.219]}\end{array}$ & $\begin{array}{c}-1.019^{* * *} \\
{[0.221]}\end{array}$ & $\begin{array}{c}-0.972^{\star * *} \\
{[0.226]}\end{array}$ & $\begin{array}{c}-1.133^{* * *} \\
{[0.211]}\end{array}$ & $\begin{array}{c}-1.094^{* * *} \\
{[0.208]}\end{array}$ & $\begin{array}{c}-1.068^{* * *} \\
{[0.206]}\end{array}$ \\
\hline Alliance (t-2) & $\begin{array}{c}0.191 \\
{[0.152]}\end{array}$ & $\begin{array}{c}0.189 \\
{[0.150]}\end{array}$ & $\begin{array}{c}0.221 \\
{[0.156]}\end{array}$ & $\begin{array}{l}0.285^{\star} \\
{[0.146]}\end{array}$ & $\begin{array}{c}0.400^{\star * *} \\
{[0.152]}\end{array}$ & $\begin{array}{l}0.327^{* *} \\
{[0.138]}\end{array}$ & $\begin{array}{l}0.313^{\star *} \\
{[0.138]}\end{array}$ & $\begin{array}{l}0.305^{\star *} \\
{[0.131]}\end{array}$ \\
\hline $\begin{array}{l}\text { Religious Similarity } \\
(\mathrm{t}-2)\end{array}$ & $\begin{array}{l}-0.276^{* \star} \\
{[0.127]}\end{array}$ & $\begin{array}{l}-0.280^{* *} \\
{[0.126]}\end{array}$ & $\begin{array}{c}-0.349^{* *} \\
{[0.150]}\end{array}$ & $\begin{array}{c}-0.266^{* *} \\
{[0.130]}\end{array}$ & $\begin{array}{l}-0.198 \\
{[0.143]}\end{array}$ & $\begin{array}{l}-0.176 \\
{[0.136]}\end{array}$ & $\begin{array}{l}-0.194 \\
{[0.136]}\end{array}$ & $\begin{array}{l}-0.194 \\
{[0.135]}\end{array}$ \\
\hline Oil exporters dummy & $\begin{array}{l}0.456^{* * *} \\
{[0.137]}\end{array}$ & $\begin{array}{l}0.442^{* * *} \\
{[0.137]}\end{array}$ & $\begin{array}{c}0.518^{* * *} \\
{[0.142]}\end{array}$ & $\begin{array}{l}0.512^{* * *} \\
{[0.140]}\end{array}$ & $\begin{array}{l}0.480^{* * *} \\
{[0.135]}\end{array}$ & $\begin{array}{c}0.394^{* * *} \\
{[0.120]}\end{array}$ & $\begin{array}{c}0.362^{* * *} \\
{[0.119]}\end{array}$ & $\begin{array}{c}0.355^{* * *} \\
{[0.118]}\end{array}$ \\
\hline $\begin{array}{l}\text { Number of peace } \\
\text { years }\end{array}$ & $\begin{array}{l}-0.135^{\star * *} \\
{[0.008]}\end{array}$ & $\begin{array}{l}-0.136^{* * *} \\
{[0.008]}\end{array}$ & $\begin{array}{c}-0.139^{* * *} \\
{[0.008]}\end{array}$ & $\begin{array}{l}-0.139^{* * *} \\
{[0.008]}\end{array}$ & $\begin{array}{l}-0.122^{* * *} \\
{[0.007]}\end{array}$ & $\begin{array}{c}-0.615^{* * *} \\
{[0.034]}\end{array}$ & $\begin{array}{c}-0.610^{* * *} \\
{[0.033]}\end{array}$ & $\begin{array}{c}-0.605^{\star * *} \\
{[0.033]}\end{array}$ \\
\hline $\begin{array}{l}\text { Number of other } \\
\text { conflicts in } t\end{array}$ & $\begin{array}{l}0.036^{* * *} \\
{[0.005]}\end{array}$ & & & & & $\begin{array}{l}0.035^{* * *} \\
{[0.009]}\end{array}$ & $\begin{array}{l}0.037^{* * *} \\
{[0.009]}\end{array}$ & $\begin{array}{c}0.037^{* * *} \\
{[0.009]}\end{array}$ \\
\hline $\begin{array}{l}\text { Zero trade dummy (t- } \\
\text { 2) }\end{array}$ & & $\begin{array}{c}-0.549^{* * *} \\
{[0.173]}\end{array}$ & & & & $\begin{array}{l}-0.232 \\
{[0.180]}\end{array}$ & $\begin{array}{l}-0.219 \\
{[0.183]}\end{array}$ & $\begin{array}{l}-0.222 \\
{[0.183]}\end{array}$ \\
\hline Common language & & & $\begin{array}{l}0.371^{* *} \\
{[0.172]}\end{array}$ & & & $\begin{array}{c}0.177 \\
{[0.166]}\end{array}$ & $\begin{array}{c}0.177 \\
{[0.165]}\end{array}$ & $\begin{array}{c}0.184 \\
{[0.162]}\end{array}$ \\
\hline $\begin{array}{l}\text { Pair ever } \\
\text { in colonial }\end{array}$ & & & & $\begin{array}{c}0.22 \\
{[0.350]}\end{array}$ & & $\begin{array}{c}0.22 \\
{[0.287]}\end{array}$ & $\begin{array}{l}0.148 \\
{[0.272]}\end{array}$ & $\begin{array}{l}0.067 \\
{[0.279]}\end{array}$ \\
\hline UN voting & & & & & $\begin{array}{c}-1.019^{\star * *} \\
{[0.194]}\end{array}$ & $\begin{array}{l}-0.854^{* * *} \\
{[0.174]}\end{array}$ & $\begin{array}{l}-0.796^{* * *} \\
{[0.169]}\end{array}$ & $\begin{array}{l}-0.833^{* * *} \\
{[0.169]}\end{array}$ \\
\hline Spline(1) & & & & & & $\begin{array}{c}5.329^{* * *} \\
{[0.396]}\end{array}$ & $\begin{array}{c}5.298^{* * *} \\
{[0.391]}\end{array}$ & $\begin{array}{c}5.255^{\star * *} \\
{[0.396]}\end{array}$ \\
\hline Spline(2) & & & & & & $\begin{array}{c}-10.344^{* * *} \\
{[0.817]}\end{array}$ & $\begin{array}{c}-10.294^{* * *} \\
{[0.810]}\end{array}$ & $\begin{array}{c}-10.212^{* \star \star *} \\
{[0.817]}\end{array}$ \\
\hline Spline(3) & & & & & & $\begin{array}{c}6.951^{* * *} \\
{[0.651]}\end{array}$ & $\begin{array}{l}6.932^{\star * \star} \\
{[0.650]}\end{array}$ & $\begin{array}{c}6.873^{\star * \star} \\
{[0.654]}\end{array}$ \\
\hline Distance $(\log ) \times$ & & & & & & & $12.948^{\star * *}$ & \\
\hline $\begin{array}{l}\text { Bilateral trade } \\
\text { dependence }\end{array}$ & & & & & & & [3.170] & \\
\hline $\begin{array}{l}\text { Distance }(\log ) \\
\times \text { Global openness }\end{array}$ & & & & & & & $\begin{array}{l}-0.402^{* *} \\
{[0.168]}\end{array}$ & \\
\hline $\begin{array}{l}\text { Contiguity } \times \text { Bilateral } \\
\text { trade dependence }\end{array}$ & & & & & & & & $\begin{array}{c}-38.847^{\star \star \star} \\
{[7.262]}\end{array}$ \\
\hline $\begin{array}{l}\text { Contiguity } \\
\times \text { Global openness }\end{array}$ & & & & & & & & $\begin{array}{l}1.238^{* *} \\
{[0.595]}\end{array}$ \\
\hline Observations & 290040 & 290040 & 255091 & 255091 & 262043 & 235477 & 235477 & 235477 \\
\hline Pseuo- $R^{2}$ & 0.378 & 0.38 & 0.372 & 0.371 & 0.373 & 0.428 & 0.432 & 0.432 \\
\hline
\end{tabular}

Note: Clustered robust standard errors are reported in bracket. Intercept and year dummy variables are included (not reported). 
Table 6: Robustness Check II (Other trade integration measurements)

\begin{tabular}{|c|c|c|c|c|c|c|c|c|}
\hline & \multicolumn{4}{|c|}{3 Years Lagged Trade Variables } & \multicolumn{4}{|c|}{$\begin{array}{l}\text { Other Trade Dependence } \\
\text { (arithmetic average) }\end{array}$} \\
\hline & (1) & (2) & (3) & (4) & (5) & $(6)$ & $(7)$ & $(8)$ \\
\hline $\begin{array}{l}\text { Bilateral trade } \\
\text { dependence }\end{array}$ & $\begin{array}{c}-7.06 \\
{[5.418]}\end{array}$ & $\begin{array}{l}-3.647 \\
{[4.831]}\end{array}$ & $\begin{array}{c}-92.907^{* * *} \\
{[25.321]}\end{array}$ & $\begin{array}{c}26.993^{* * *} \\
{[5.544]}\end{array}$ & $\begin{array}{l}-1.389 \\
{[1.039]}\end{array}$ & $\begin{array}{c}-0.76 \\
{[1.035]}\end{array}$ & $\begin{array}{c}-16.548^{* * *} \\
{[4.313]}\end{array}$ & $\begin{array}{c}2.542^{* * *} \\
{[0.418]}\end{array}$ \\
\hline $\begin{array}{l}\text { Global trade } \\
\text { openness }\end{array}$ & $\begin{array}{c}-1.838^{* * *} \\
{[0.417]}\end{array}$ & $\begin{array}{l}-0.934^{* *} \\
{[0.421]}\end{array}$ & $\begin{array}{l}2.432^{*} \\
{[1.324]}\end{array}$ & $\begin{array}{c}-2.137^{* * *} \\
{[0.683]}\end{array}$ & $\begin{array}{c}-0.672^{* * *} \\
{[0.113]}\end{array}$ & $\begin{array}{c}-0.478^{* * *} \\
{[0.106]}\end{array}$ & $\begin{array}{c}0.387 \\
{[0.518]}\end{array}$ & $\begin{array}{c}-0.697^{* * *} \\
{[0.126]}\end{array}$ \\
\hline Contiguity & $\begin{array}{c}2.027^{* * *} \\
{[0.184]}\end{array}$ & $\begin{array}{l}1.811^{* * *} \\
{[0.197]}\end{array}$ & $\begin{array}{l}1.786^{* * *} \\
{[0.196]}\end{array}$ & $\begin{array}{l}1.410^{* * *} \\
{[0.296]}\end{array}$ & $\begin{array}{c}2.062^{* * *} \\
{[0.185]}\end{array}$ & $\begin{array}{l}1.852^{\star * *} \\
{[0.193]}\end{array}$ & $\begin{array}{l}1.866^{\star * *} \\
{[0.196]}\end{array}$ & $\begin{array}{c}2.232^{* * *} \\
{[0.229]}\end{array}$ \\
\hline Distance(Log) & $\begin{array}{l}-0.444^{\star * *} \\
{[0.075]}\end{array}$ & $\begin{array}{c}-0.359^{* * *} \\
{[0.077]}\end{array}$ & $\begin{array}{l}-0.228^{* *} \\
{[0.106]}\end{array}$ & $\begin{array}{c}-0.323^{\star * *} \\
{[0.073]}\end{array}$ & $\begin{array}{c}-0.484^{* * *} \\
{[0.075]}\end{array}$ & $\begin{array}{c}-0.396^{* * *} \\
{[0.078]}\end{array}$ & $\begin{array}{l}-0.468^{\star * *} \\
{[0.096]}\end{array}$ & $\begin{array}{l}-0.376^{* * *} \\
{[0.080]}\end{array}$ \\
\hline $\begin{array}{l}\text { Log difference } \\
\text { of GDP }\end{array}$ & $\begin{array}{c}-0.126^{* * *} \\
{[0.031]}\end{array}$ & $\begin{array}{l}-0.068^{* *} \\
{[0.029]}\end{array}$ & $\begin{array}{l}-0.067^{* *} \\
{[0.029]}\end{array}$ & $\begin{array}{c}-0.075^{* * *} \\
{[0.029]}\end{array}$ & $\begin{array}{c}-0.088^{* * *} \\
{[0.032]}\end{array}$ & $\begin{array}{l}-0.044 \\
{[0.031]}\end{array}$ & $\begin{array}{l}-0.053^{*} \\
{[0.031]}\end{array}$ & $\begin{array}{c}-0.069^{* *} \\
{[0.030]}\end{array}$ \\
\hline $\begin{array}{l}\text { Major powers } \\
\text { dummy }\end{array}$ & $\begin{array}{l}1.728^{\star \star \star} \\
{[0.169]}\end{array}$ & $\begin{array}{l}1.264^{\star \star *} \\
{[0.172]}\end{array}$ & $\begin{array}{l}1.157^{\star \star \star} \\
{[0.167]}\end{array}$ & $\begin{array}{l}1.169^{* * *} \\
{[0.166]}\end{array}$ & $\begin{array}{l}1.766^{\star * *} \\
{[0.172]}\end{array}$ & $\begin{array}{l}1.213^{\star \star \star} \\
{[0.168]}\end{array}$ & $\begin{array}{l}1.196^{\star \star \star} \\
{[0.169]}\end{array}$ & $\begin{array}{l}1.212^{\star * *} \\
{[0.170]}\end{array}$ \\
\hline $\begin{array}{l}\text { Joint democracy } \\
\text { index }\end{array}$ & $\begin{array}{c}-0.903^{* * *} \\
{[0.208]}\end{array}$ & $\begin{array}{c}-0.973^{* * *} \\
{[0.200]}\end{array}$ & $\begin{array}{l}-0.934^{* * *} \\
{[0.199]}\end{array}$ & $\begin{array}{c}-0.904^{* * *} \\
{[0.195]}\end{array}$ & $\begin{array}{c}-1.021^{* * *} \\
{[0.214]}\end{array}$ & $\begin{array}{c}-1.129^{* * *} \\
{[0.211]}\end{array}$ & $\begin{array}{c}-1.038^{* * *} \\
{[0.205]}\end{array}$ & $\begin{array}{c}-1.012^{* * *} \\
{[0.204]}\end{array}$ \\
\hline Alliance & $\begin{array}{c}0.173 \\
{[0.149]}\end{array}$ & $\begin{array}{l}0.225^{*} \\
{[0.136]}\end{array}$ & $\begin{array}{c}0.207 \\
{[0.135]}\end{array}$ & $\begin{array}{c}0.187 \\
{[0.128]}\end{array}$ & $\begin{array}{c}0.124 \\
{[0.154]}\end{array}$ & $\begin{array}{l}0.288^{* *} \\
{[0.137]}\end{array}$ & $\begin{array}{l}0.275^{\star *} \\
{[0.137]}\end{array}$ & $\begin{array}{c}0.247^{*} \\
{[0.128]}\end{array}$ \\
\hline Religious Similarity & $\begin{array}{c}-0.267^{* *} \\
{[0.125]}\end{array}$ & $\begin{array}{l}-0.175 \\
{[0.129]}\end{array}$ & $\begin{array}{l}-0.196 \\
{[0.129]}\end{array}$ & $\begin{array}{l}-0.202 \\
{[0.129]}\end{array}$ & $\begin{array}{l}-0.277^{* *} \\
{[0.129]}\end{array}$ & $\begin{array}{l}-0.166 \\
{[0.133]}\end{array}$ & $\begin{array}{l}-0.175 \\
{[0.132]}\end{array}$ & $\begin{array}{c}-0.18 \\
{[0.131]}\end{array}$ \\
\hline $\begin{array}{l}\text { Oil exporters } \\
\text { dummy }\end{array}$ & $\begin{array}{c}0.454^{* * *} \\
{[0.135]}\end{array}$ & $\begin{array}{c}0.425^{\star * *} \\
{[0.118]}\end{array}$ & $\begin{array}{l}0.389^{* * *} \\
{[0.117]}\end{array}$ & $\begin{array}{c}0.380^{* * *} \\
{[0.114]}\end{array}$ & $\begin{array}{c}0.472^{* * *} \\
{[0.141]}\end{array}$ & $\begin{array}{c}0.431^{* * *} \\
{[0.122]}\end{array}$ & $\begin{array}{c}0.426^{* * *} \\
{[0.123]}\end{array}$ & $\begin{array}{c}0.413^{* * *} \\
{[0.121]}\end{array}$ \\
\hline $\begin{array}{l}\text { Number of } \\
\text { peace years }\end{array}$ & $\begin{array}{c}-0.138^{\star \star \star} \\
{[0.008]}\end{array}$ & $\begin{array}{c}-0.598^{* * *} \\
{[0.032]}\end{array}$ & $\begin{array}{c}-0.593^{* * *} \\
{[0.031]}\end{array}$ & $\begin{array}{c}-0.588^{* * *} \\
{[0.031]}\end{array}$ & $\begin{array}{c}-0.136^{* * *} \\
{[0.008]}\end{array}$ & $\begin{array}{c}-0.613^{\star \star \star} \\
{[0.033]}\end{array}$ & $\begin{array}{c}-0.608^{\star * *} \\
{[0.033]}\end{array}$ & $\begin{array}{c}-0.601^{* * *} \\
{[0.034]}\end{array}$ \\
\hline $\begin{array}{l}\text { Number of other } \\
\text { conflicts in } \mathrm{t}\end{array}$ & & $\begin{array}{l}0.033^{* * *} \\
{[0.009]}\end{array}$ & $\begin{array}{l}0.035^{\star * *} \\
{[0.009]}\end{array}$ & $\begin{array}{l}0.036^{* * *} \\
{[0.009]}\end{array}$ & & $\begin{array}{l}0.036^{* * *} \\
{[0.009]}\end{array}$ & $\begin{array}{l}0.037^{* * *} \\
{[0.009]}\end{array}$ & $\begin{array}{c}0.038^{* * *} \\
{[0.009]}\end{array}$ \\
\hline $\begin{array}{l}\text { Zero trade } \\
\text { dummy }\end{array}$ & & $\begin{array}{l}{[.00]} \\
-0.235 \\
{[0.207]}\end{array}$ & $\begin{array}{l}-0.217 \\
{[0.210]}\end{array}$ & $\begin{array}{l}-0.221 \\
{[0.211]}\end{array}$ & & $\begin{array}{l}{[.0 .221} \\
-0.179]\end{array}$ & $\begin{array}{l}{[.0 .232} \\
-0.182]\end{array}$ & $\begin{array}{l}{[.000]} \\
-0.245 \\
{[0.183]}\end{array}$ \\
\hline Common language & & $\begin{array}{c}0.166 \\
{[0.161]}\end{array}$ & $\begin{array}{c}0.168 \\
{[0.161]}\end{array}$ & $\begin{array}{c}0.178 \\
{[0.158]}\end{array}$ & & $\begin{array}{c}0.184 \\
{[0.164]}\end{array}$ & $\begin{array}{c}0.176 \\
{[0.164]}\end{array}$ & $\begin{array}{c}0.181 \\
{[0.160]}\end{array}$ \\
\hline $\begin{array}{l}\text { Pair ever in } \\
\text { colonial relationship }\end{array}$ & & $\begin{array}{c}0.244 \\
{[0.274]}\end{array}$ & $\begin{array}{c}0.169 \\
{[0.256]}\end{array}$ & $\begin{array}{c}0.104 \\
{[0.265]}\end{array}$ & & $\begin{array}{c}0.255 \\
{[0.286]}\end{array}$ & $\begin{array}{c}0.242 \\
{[0.273]}\end{array}$ & $\begin{array}{c}0.143 \\
{[0.277]}\end{array}$ \\
\hline UN voting & & $\begin{array}{c}-0.712^{* * *} \\
{[0.165]}\end{array}$ & $\begin{array}{c}-0.656^{* * *} \\
{[0.159]}\end{array}$ & $\begin{array}{c}-0.692^{* * *} \\
{[0.159]}\end{array}$ & & $\begin{array}{c}-0.853^{* * *} \\
{[0.173]}\end{array}$ & $\begin{array}{c}-0.810^{* * *} \\
{[0.172]}\end{array}$ & $\begin{array}{c}-0.822^{* * *} \\
{[0.170]}\end{array}$ \\
\hline Spline(1) & & $\begin{array}{l}4.952^{* * *} \\
{[0.369]}\end{array}$ & $\begin{array}{l}4.925^{\star * *} \\
{[0.366]}\end{array}$ & $\begin{array}{l}4.891^{* * *} \\
{[0.370]}\end{array}$ & & $\begin{array}{c}5.307^{* * *} \\
{[0.391]}\end{array}$ & $\begin{array}{c}5.277^{* * *} \\
{[0.393]}\end{array}$ & $\begin{array}{c}5.216^{* * *} \\
{[0.397]}\end{array}$ \\
\hline Spline(2) & & $\begin{array}{c}-9.517^{* * *} \\
{[0.766]}\end{array}$ & $\begin{array}{l}-9.474^{* * *} \\
{[0.763]}\end{array}$ & $\begin{array}{c}-9.411^{* * *} \\
{[0.770]}\end{array}$ & & $\begin{array}{c}-10.307^{* * *} \\
{[0.808]}\end{array}$ & $\begin{array}{c}-10.249^{* * *} \\
{[0.811]}\end{array}$ & $\begin{array}{c}-10.127^{* * *} \\
{[0.820]}\end{array}$ \\
\hline Spline(3) & & $\begin{array}{l}6.271^{* * *} \\
{[0.624]}\end{array}$ & $\begin{array}{c}6.253^{* * *} \\
{[0.625]}\end{array}$ & $\begin{array}{l}6.209^{* * *} \\
{[0.628]}\end{array}$ & & $\begin{array}{l}6.935^{* * *} \\
{[0.647]}\end{array}$ & $\begin{array}{c}6.894^{* * *} \\
{[0.649]}\end{array}$ & $\begin{array}{c}6.798^{* * *} \\
{[0.655]}\end{array}$ \\
\hline $\begin{array}{l}\text { Distance }(\log ) \times \\
\text { Bilateral trade }\end{array}$ & & & $\begin{array}{c}13.231^{\star \star \star} \\
{[3.134]}\end{array}$ & & & & $\begin{array}{l}2.038^{\star \star *} \\
{[0.470]}\end{array}$ & \\
\hline $\begin{array}{l}\text { dependence } \\
\text { Distance(log) } \\
\times \text { Global openness }\end{array}$ & & & $\begin{array}{l}-0.488^{* * *} \\
{[0.187]}\end{array}$ & & & & $\begin{array}{l}-0.116^{*} \\
{[0.066]}\end{array}$ & \\
\hline Contiguity $x$ & & & & $-38.929^{* * *}$ & & & & $-7.551^{* * *}$ \\
\hline $\begin{array}{l}\text { Bilateral trade } \\
\text { dependence }\end{array}$ & & & & [6.945] & & & & {$[1.447]$} \\
\hline $\begin{array}{l}\text { Contiguity } \\
\times \text { Global openness }\end{array}$ & & & & $\begin{array}{c}1.835^{\star * *} \\
{[0.703]}\end{array}$ & & & & $\begin{array}{l}0.381^{* *} \\
{[0.162]}\end{array}$ \\
\hline Observations & 265646 & 216877 & 216877 & 216877 & 290040 & 235477 & 235477 & 235477 \\
\hline
\end{tabular}

Note: trade openness measures from column (5) to (8) are constructed by log of the arithmetic averages, rather than the geometric averages, of bilateral or global trade openness of the two countries. 
Table 7: Instrument Variable Estimation: First Stage Regression

\begin{tabular}{|c|c|c|}
\hline Dependent Variables & Bilateral Trade Dependence & Global Trade Openness \\
\hline \multirow[t]{2}{*}{ EU GSP IV } & $-0.00005^{\star * *}$ & $0.0028^{* * *}$ \\
\hline & {$[0.00002]$} & {$[0.0009]$} \\
\hline \multirow{2}{*}{ Remoteness IV } & $0.0019^{* \star \star}$ & $-0.0298^{\star * *}$ \\
\hline & {$[0.0007]$} & {$[0.0091]$} \\
\hline \multirow{2}{*}{ Number of trading partners IV } & $0.00004^{* * *}$ & $0.0006^{* * *}$ \\
\hline & {$[0.00001]$} & {$[0.0001]$} \\
\hline \multirow{2}{*}{ Contiguity } & $0.0061^{\star * *}$ & $-0.1026^{\star \star \star}$ \\
\hline & {$[0.001]$} & {$[0.0139]$} \\
\hline \multirow{2}{*}{ Distance(Log) } & $-0.0022^{* * *}$ & $-0.0276^{* * *}$ \\
\hline & {$[0.0003]$} & {$[0.0045]$} \\
\hline \multirow{2}{*}{ Log difference of GDP(t-2) } & -0.00005 & $0.0099^{* * *}$ \\
\hline & {$[0.00003]$} & {$[0.0021]$} \\
\hline \multirow{2}{*}{ Major powers dummy } & $0.0034^{* * *}$ & $-0.1531^{\star \star *}$ \\
\hline & {$[0.0004]$} & {$[0.0076]$} \\
\hline \multirow{2}{*}{ Joint democracy index(t-2) } & $0.002^{* \star *}$ & $0.0437^{\star * *}$ \\
\hline & {$[0.0003]$} & {$[0.0071]$} \\
\hline \multirow{2}{*}{ Alliance(t-2) } & 0.00001 & $-0.0222^{\star *}$ \\
\hline & {$[0.0006]$} & [0.0093] \\
\hline \multirow{2}{*}{ Religious Similarity(t-2) } & $-0.0003^{* * *}$ & $-0.0074^{*}$ \\
\hline & {$[0.0001]$} & {$[0.0043]$} \\
\hline \multirow{2}{*}{ Oil exporters dummy } & $0.0014^{* * *}$ & $0.0661^{* * *}$ \\
\hline & {$[0.0002]$} & {$[0.0068]$} \\
\hline \multirow{2}{*}{ Number of peace years } & $0.0002^{* *}$ & $0.0233^{* * *}$ \\
\hline & {$[0.00007]$} & {$[0.0018]$} \\
\hline \multirow{2}{*}{ Number of other conflicts in $t$} & $-0.0002^{* *}$ & -0.0007 \\
\hline & {$[0.00009]$} & {$[0.0023]$} \\
\hline \multirow{2}{*}{ Zero trade dummy(t-2) } & -0.0005 & $0.0735^{* * *}$ \\
\hline & {$[0.0001]$} & {$[0.0097]$} \\
\hline \multirow{2}{*}{ Common language } & 0.0002 & $0.0749^{\star * \star}$ \\
\hline & {$[0.0002]$} & {$[0.0097]$} \\
\hline \multirow{2}{*}{$\begin{array}{l}\text { Pair ever in colonial } \\
\text { relationship }\end{array}$} & $0.0064^{* * *}$ & $-0.0522^{\star \star *}$ \\
\hline & {$[0.0016]$} & {$[0.0155]$} \\
\hline \multirow{2}{*}{ UN voting(t-2) } & -0.00004 & $0.0409^{* * *}$ \\
\hline & {$[0.0002]$} & {$[0.0085]$} \\
\hline F-test on IVs & 14.25 & 35.07 \\
\hline Observations & 229542 & 229542 \\
\hline R-square & 0.1745 & 0.1337 \\
\hline
\end{tabular}

Note: Robust standard errors clustered by dyads are in parentheses. All regressions include unreported year dummies and cublic splines of number of peace years. The first stage regressions which include interaction terms with distance and contiguity are similar with the above result. Moreover, the results of first stage regression of IV probit are qualitatively same as the above. 
Table 8: Instrument Variable Estimation: Second Stage IV Regression

\begin{tabular}{|c|c|c|c|c|}
\hline & (1) & (2) & (3) & (4) \\
\hline Bilateral trade dependence $(\mathrm{t}-2)$ & $\begin{array}{c}-1.511^{\star *} \\
{[0.631]}\end{array}$ & $\begin{array}{l}-34.274 \\
{[35.228]}\end{array}$ & $\begin{array}{l}-6.596^{*} \\
{[3.643]}\end{array}$ & $\begin{array}{l}-1.092 \\
{[1.771]}\end{array}$ \\
\hline Global trade openness(t-2) & $\begin{array}{l}-0.043^{* * *} \\
{[0.014]}\end{array}$ & $\begin{array}{l}-1.494^{*} \\
{[0.776]}\end{array}$ & $\begin{array}{c}0.003 \\
{[0.101]}\end{array}$ & $\begin{array}{c}-0.047^{* \star *} \\
{[0.014]}\end{array}$ \\
\hline Contiguity & $\begin{array}{l}0.06^{\star \star \star} \\
{[0.008]}\end{array}$ & $\begin{array}{c}0.883^{* * *} \\
{[0.275]}\end{array}$ & $\begin{array}{l}0.06^{* * *} \\
{[0.009]}\end{array}$ & $\begin{array}{c}0.109 \\
{[0.067]}\end{array}$ \\
\hline Distance(Log) & $\begin{array}{c}-0.005^{\star * *} \\
{[0.001]}\end{array}$ & $\begin{array}{l}-0.267^{* * *} \\
{[0.060]}\end{array}$ & $\begin{array}{l}-0.003 \\
{[0.006]}\end{array}$ & $\begin{array}{c}-0.005^{\star *} \\
{[0.002]}\end{array}$ \\
\hline Log difference of GDP(t-2) & $\begin{array}{l}-0.0001 \\
{[0.0002]}\end{array}$ & $\begin{array}{c}-0.02 \\
{[0.014]}\end{array}$ & $\begin{array}{c}0.0001 \\
{[0.0002]}\end{array}$ & $\begin{array}{r}-0.00002 \\
{[0.0002]}\end{array}$ \\
\hline Major powers dummy & $\begin{array}{l}0.006^{*} \\
{[0.003]}\end{array}$ & $\begin{array}{l}0.451^{* *} \\
{[0.186]}\end{array}$ & $\begin{array}{l}-0.001 \\
{[0.004]}\end{array}$ & $\begin{array}{c}0.004 \\
{[0.004]}\end{array}$ \\
\hline Joint democracy index(t-2) & $\begin{array}{l}-0.0004 \\
{[0.002]}\end{array}$ & $\begin{array}{c}-0.265^{\star *} \\
{[0.110]}\end{array}$ & $\begin{array}{l}-0.001 \\
{[0.002]}\end{array}$ & $\begin{array}{l}-0.0005 \\
{[0.002]}\end{array}$ \\
\hline Alliance(t-2) & $\begin{array}{l}-0.002 \\
{[0.002]}\end{array}$ & $\begin{array}{c}0.074 \\
{[0.076]}\end{array}$ & $\begin{array}{l}-0.005^{\star *} \\
{[0.002]}\end{array}$ & $\begin{array}{l}-0.003 \\
{[0.003]}\end{array}$ \\
\hline Religious Similarity(t-2) & $\begin{array}{c}-0.002^{* * *} \\
{[0.001]}\end{array}$ & $\begin{array}{l}-0.092^{*} \\
{[0.049]}\end{array}$ & $\begin{array}{l}-0.001^{* *} \\
{[0.001]}\end{array}$ & $\begin{array}{l}-0.002^{* *} \\
{[0.001]}\end{array}$ \\
\hline Oil exporters dummy & $\begin{array}{l}0.005^{\star * *} \\
{[0.002]}\end{array}$ & $\begin{array}{l}0.261^{* \star *} \\
{[0.082]}\end{array}$ & $\begin{array}{c}0.004 \\
{[0.002]}\end{array}$ & $\begin{array}{l}0.006^{*} \\
{[0.003]}\end{array}$ \\
\hline Number of peace years & $\begin{array}{c}-0.021^{* * *} \\
{[0.002]}\end{array}$ & $\begin{array}{l}-0.256^{* * *} \\
{[0.022]}\end{array}$ & $\begin{array}{c}-0.020^{* * *} \\
{[0.002]}\end{array}$ & $\begin{array}{c}-0.020^{* * *} \\
{[0.002]}\end{array}$ \\
\hline Number of other conflicts in $t$ & $\begin{array}{l}0.025^{\star * *} \\
{[0.002]}\end{array}$ & $\begin{array}{l}0.020^{* * *} \\
{[0.008]}\end{array}$ & $\begin{array}{l}0.024^{* * *} \\
{[0.002]}\end{array}$ & $\begin{array}{c}0.024^{* * *} \\
{[0.002]}\end{array}$ \\
\hline Zero trade dummy(t-2) & $\begin{array}{l}0.003^{* *} \\
{[0.001]}\end{array}$ & $\begin{array}{l}-0.002 \\
{[0.100]}\end{array}$ & $\begin{array}{l}0.006^{* * *} \\
{[0.002]}\end{array}$ & $\begin{array}{c}0.004 \\
{[0.002]}\end{array}$ \\
\hline Common language & $\begin{array}{l}0.005^{\star * *} \\
{[0.002]}\end{array}$ & $\begin{array}{l}0.148^{*} \\
{[0.085]}\end{array}$ & $\begin{array}{l}0.006^{* * *} \\
{[0.001]}\end{array}$ & $\begin{array}{c}0.006^{\star \star \star} \\
{[0.001]}\end{array}$ \\
\hline $\begin{array}{l}\text { Pair ever in colonial } \\
\text { relationship }\end{array}$ & $\begin{array}{c}0.007 \\
{[0.007]}\end{array}$ & $\begin{array}{c}0.223 \\
{[0.291]}\end{array}$ & $\begin{array}{l}-0.005 \\
{[0.008]}\end{array}$ & $\begin{array}{c}0.003 \\
{[0.008]}\end{array}$ \\
\hline UN voting (t-2) & $\begin{array}{l}-0.005^{\star \star \star} \\
{[0.001]}\end{array}$ & $\begin{array}{l}-0.284^{* * *} \\
{[0.067]}\end{array}$ & $\begin{array}{l}-0.003^{*} \\
{[0.002]}\end{array}$ & $\begin{array}{c}-0.005^{\star * *} \\
{[0.002]}\end{array}$ \\
\hline Spline(1) & $\begin{array}{l}0.171^{* * *} \\
{[0.015]}\end{array}$ & $\begin{array}{c}2.096^{* * *} \\
{[0.212]}\end{array}$ & $\begin{array}{c}0.162^{* * *} \\
{[0.015]}\end{array}$ & $\begin{array}{c}0.165^{\star * *} \\
{[0.014]}\end{array}$ \\
\hline Spline(2) & $\begin{array}{l}-0.315^{\star \star *} \\
{[0.027]}\end{array}$ & $\begin{array}{l}-4.009^{* * *} \\
{[0.398]}\end{array}$ & $\begin{array}{c}-0.298^{* * *} \\
{[0.027]}\end{array}$ & $\begin{array}{c}-0.303^{* * *} \\
{[0.025]}\end{array}$ \\
\hline Spline(3) & $\begin{array}{l}0.176^{* * *} \\
{[0.015]}\end{array}$ & $\begin{array}{l}2.601^{* * *} \\
{[0.261]}\end{array}$ & $\begin{array}{l}0.167^{* * *} \\
{[0.015]}\end{array}$ & $\begin{array}{c}0.170^{\star * \star} \\
{[0.014]}\end{array}$ \\
\hline $\begin{array}{l}\text { Distance }(\log ) \times \text { Bilateral trade } \\
\text { dependence }\end{array}$ & & & $\begin{array}{c}0.829 \\
{[0.550]}\end{array}$ & \\
\hline $\begin{array}{l}\text { Distance }(\text { log }) \\
\times \text { Global openness }\end{array}$ & & & $\begin{array}{l}-0.007 \\
{[0.012]}\end{array}$ & \\
\hline $\begin{array}{l}\text { Contiguity } \times \text { Bilateral trade } \\
\text { dependence }\end{array}$ & & & & $\begin{array}{l}-0.257 \\
{[4.166]}\end{array}$ \\
\hline $\begin{array}{l}\text { Contiguity } \\
\times \text { Global openness }\end{array}$ & & & & $\begin{array}{l}-0.122 \\
{[0.235]}\end{array}$ \\
\hline & IV LPM & IV Probit & IV LPM & IV LPM \\
\hline Observations & 229542 & 229542 & 229542 & 229542 \\
\hline$R^{2}$ & 0.0521 & - & 0.0298 & 0.0361 \\
\hline
\end{tabular}

Note: Clustered robust standard errors by dyads and bootstrap standard errors - column (2)- are reported. IV probit estimation with clustered bootstrap is reported in column (2). 
Table 9: Impact of Military Conflicts on Bilateral Trade Dependence

\begin{tabular}{|c|c|c|}
\hline \multirow[t]{2}{*}{ Dependent Variable } & \multicolumn{2}{|c|}{ Bilateral Trade Dependence } \\
\hline & (1) & $(2)$ \\
\hline \multirow[t]{2}{*}{ Conflict(t) } & $-0.00126^{* * *}$ & -0.00035 \\
\hline & {$[0.00035]$} & {$[0.00023]$} \\
\hline \multirow[t]{2}{*}{ Conflict(t-1) } & $-0.00118^{* \star *}$ & $-0.0006^{\star * *}$ \\
\hline & {$[0.00028]$} & {$[0.00018]$} \\
\hline \multirow[t]{2}{*}{ Conflict(t-2) } & $-0.00108^{* * *}$ & $-0.0005^{\star * *}$ \\
\hline & {$[0.00026]$} & {$[0.00019]$} \\
\hline \multirow[t]{2}{*}{ Conflict(t-3) } & $-0.00095^{* * *}$ & $-0.00032^{\star *}$ \\
\hline & {$[0.00026]$} & {$[0.00016]$} \\
\hline \multirow[t]{2}{*}{ Conflict(t-4) } & $-0.00097^{* * *}$ & $-0.00056^{* * *}$ \\
\hline & {$[0.00031]$} & {$[0.00015]$} \\
\hline \multirow[t]{2}{*}{ Conflict(t-5) } & $-0.00141^{* * *}$ & $-0.00063^{* * *}$ \\
\hline & {$[0.00035]$} & {$[0.00021]$} \\
\hline \multirow[t]{2}{*}{ Square root of Product Real GDP } & $0.00898^{* * *}$ & $0.00436^{* * *}$ \\
\hline & {$[0.00125]$} & {$[0.00095]$} \\
\hline \multirow{2}{*}{$\begin{array}{l}\text { Square root of Product Real GDP } \\
\text { per capita }\end{array}$} & $0.13013^{* * *}$ & $-0.06969^{* *}$ \\
\hline & {$[0.02211]$} & {$[0.02716]$} \\
\hline \multirow[t]{2}{*}{ Remoteness } & $0.00111^{* * *}$ & $0.00343^{* * *}$ \\
\hline & {$[0.00042]$} & {$[0.00096]$} \\
\hline \multirow[t]{2}{*}{ Number of trading partners } & $0.00002^{* * *}$ & $0.00004^{* * *}$ \\
\hline & {$[0.00001]$} & {$[0.00001]$} \\
\hline \multirow[t]{2}{*}{ GSP dummy } & 0.00004 & $-0.00045^{\star * *}$ \\
\hline & {$[0.00012]$} & {$[0.00011]$} \\
\hline \multirow[t]{2}{*}{ Contiguity } & $0.0063^{* * *}$ & - \\
\hline & {$[0.0011]$} & \\
\hline \multirow[t]{2}{*}{ Distance(log) } & $-0.0017^{\star \star \star}$ & - \\
\hline & {$[0.0002]$} & \\
\hline \multirow[t]{2}{*}{ Log Product land areas } & -0.00005 & - \\
\hline & {$[0.00003]$} & \\
\hline \multirow[t]{2}{*}{ Common language } & -0.00003 & - \\
\hline & {$[0.00032]$} & \\
\hline \multirow[t]{2}{*}{ Common colonizers } & 0.0005 & - \\
\hline & {$[0.00051]$} & \\
\hline \multirow[t]{2}{*}{ Pair ever in colonial relationship } & $0.00678^{* * *}$ & \\
\hline & {$[0.00136]$} & \\
\hline \multirow[t]{2}{*}{ RTA dummy } & $0.01582^{* \star *}$ & $0.00771^{* * *}$ \\
\hline & {$[0.00229]$} & {$[0.00110]$} \\
\hline \multirow[t]{3}{*}{ Both GATT members dummy } & 0.00014 & $0.0002^{* \star}$ \\
\hline & {$[0.00010]$} & {$[0.00008]$} \\
\hline & OLS & Fixed Effect \\
\hline Observations & 251502 & 251502 \\
\hline R-squared & 0.248 & 0.794 \\
\hline
\end{tabular}

Note: Robust standard errors clustered by dyads are in parentheses. All regressions include unreported year dummies. The results without the contemporaneous military conflict $(t)$ is also qualitatively the same. 
Table 10: Impact of Military Conflicts on Global Trade Integration

\begin{tabular}{|c|c|c|}
\hline \multirow[t]{2}{*}{ Dependent Variable } & \multicolumn{2}{|c|}{ Global Trade Integration } \\
\hline & (1) & $(2)$ \\
\hline \multirow[t]{2}{*}{ Conflict(t) } & $-0.02046^{* \star *}$ & 0.00683 \\
\hline & {$[0.00668]$} & {$[0.00476]$} \\
\hline \multirow[t]{2}{*}{ Conflict(t-1) } & $-0.03115^{* * *}$ & $-0.01038^{* *}$ \\
\hline & {$[0.00533]$} & {$[0.00467]$} \\
\hline \multirow[t]{2}{*}{ Conflict(t-2) } & $-0.02664^{* * *}$ & $-0.00606^{*}$ \\
\hline & {$[0.00520]$} & {$[0.00338]$} \\
\hline \multirow[t]{2}{*}{ Conflict(t-3) } & $-0.01994^{* \star *}$ & 0.00186 \\
\hline & {$[0.00487]$} & {$[0.00356]$} \\
\hline \multirow[t]{2}{*}{ Conflict(t-4) } & $-0.02454^{* * *}$ & -0.00163 \\
\hline & {$[0.00436]$} & [0.00398] \\
\hline \multirow[t]{2}{*}{ Conflict(t-5) } & $-0.03254^{\star * *}$ & -0.00361 \\
\hline & {$[0.00565]$} & {$[0.00471]$} \\
\hline \multirow{2}{*}{$\begin{array}{l}\text { Square root of Product Real GDP of } \\
\text { Partners of dyads }(i, j)\end{array}$} & $0.04436^{* * *}$ & $0.01483^{* * *}$ \\
\hline & {$[0.00160]$} & {$[0.00187]$} \\
\hline \multirow{2}{*}{$\begin{array}{l}\text { Square root of Product Real GDP per } \\
\text { capita of Partners of dyads }(i, j)\end{array}$} & $0.03175^{\star * *}$ & $-0.00881^{* \star *}$ \\
\hline & [0.00182] & {$[0.00256]$} \\
\hline \multirow[t]{2}{*}{ Remoteness } & $-0.01174^{*}$ & $0.57537^{* * *}$ \\
\hline & [0.00712] & {$[0.04236]$} \\
\hline \multirow[t]{2}{*}{ Number of trading partners } & $0.00081^{* * *}$ & $0.00341^{* * *}$ \\
\hline & {$[0.00010]$} & {$[0.00025]$} \\
\hline \multirow[t]{2}{*}{ EU GSP*Distance(t-2) } & $0.00178^{* *}$ & -0.00055 \\
\hline & {$[0.00079]$} & {$[0.00067]$} \\
\hline \multirow[t]{2}{*}{ Contiguity } & $-0.05680^{\star * \star}$ & - \\
\hline & {$[0.01338]$} & \\
\hline \multirow[t]{2}{*}{ Distance(log) } & $-0.01989^{* * *}$ & - \\
\hline & {$[0.00383]$} & \\
\hline \multirow[t]{2}{*}{ Number of other conflicts in $t$} & $-0.00580^{\star \star *}$ & $-0.00125^{\star \star *}$ \\
\hline & {$[0.00031]$} & {$[0.00040]$} \\
\hline One of dyads in GATT & $0.05877^{* * *}$ & $0.01906^{\star * *}$ \\
\hline (Excluding Both GATT) & {$[0.00560]$} & {$[0.00443]$} \\
\hline \multirow[t]{2}{*}{ RTA between $i$ and $j$} & -0.01203 & 0.01064 \\
\hline & {$[0.01856]$} & {$[0.01266]$} \\
\hline \multirow{3}{*}{$\begin{array}{l}\text { Number of countries in Common } \\
\text { language with dyads }(i, j)\end{array}$} & $0.00116^{\star * *}$ & $0.00078^{* * *}$ \\
\hline & {$[0.00010]$} & {$[0.00019]$} \\
\hline & OLS & Fixed Effect \\
\hline Observations & 231020 & 231020 \\
\hline R-squared & 0.182 & 0.680 \\
\hline
\end{tabular}

Note: Robust standard errors clustered by dyads are in parentheses. All regressions include unreported year dummies. The results without the contemporaneous military conflict(t) is also qualitatively the same. 


\section{ADB Working Paper Series on Regional Economic Integration*}

1. "The ASEAN Economic Community and the European Experience" by Michael G. Plummer

2. "Economic Integration in East Asia: Trends, Prospects, and a Possible Roadmap" by Pradumna B. Rana

3. "Central Asia after Fifteen Years of Transition: Growth, Regional Cooperation, and Policy Choices" by Malcolm Dowling and Ganeshan Wignaraja

4. "Global Imbalances and the Asian Economies: Implications for Regional Cooperation" by Barry Eichengreen

5. "Toward Win-Win Regionalism in Asia: Issues and Challenges in Forming Efficient Trade Agreements" by Michael G. Plummer

6. "Liberalizing Cross-Border Capital Flows: How Effective Are Institutional Arrangements against Crisis in Southeast Asia" by Alfred Steinherr, Alessandro Cisotta, Erik Klär, and Kenan Šehović

7. "Managing the Noodle Bowl: The Fragility of East Asian Regionalism" by Richard E. Baldwin

8. "Measuring Regional Market Integration in Developing Asia: a Dynamic Factor Error Correction Model (DF-ECM) Approach" by Duo Qin, Marie Anne Cagas, Geoffrey Ducanes, Nedelyn Magtibay-Ramos, and Pilipinas F. Quising

9. "The Post-Crisis Sequencing of Economic Integration in Asia: Trade as a Complement to a Monetary Future" by Michael G. Plummer and Ganeshan Wignaraja

10. "Trade Intensity and Business Cycle Synchronization: The Case of East Asia" by Pradumna B. Rana

11. "Inequality and Growth Revisited" by Robert J. Barro

12. "Securitization in East Asia" by Paul Lejot, Douglas Arner, and Lotte Schou-Zibell

13. "Patterns and Determinants of Cross-border Financial Asset Holdings in East Asia" by Jong-Wha Lee

14. "Regionalism as an Engine of Multilateralism: A Case for a Single East Asian FTA" by Masahiro Kawai and Ganeshan Wignaraja

15. "The Impact of Capital Inflows on Emerging East Asian Economies: Is Too Much Money Chasing Too Little Good?" by Soyoung Kim and Doo Yong Yang

16. "Emerging East Asian Banking Systems Ten Years after the 1997/98 Crisis" by Charles Adams

17. "Real and Financial Integration in East Asia" by So young Kim and Jong-Wha Lee

18. "Global Financial Turmoil: Impact and Challenges for Asia's Financial Systems" by Jong-Wha Lee and Cyn-Young Park

19. "Cambodia's Persistent Dollarization: Causes and Policy Options" by Jayant Menon

20. "Welfare Implications of International Financial Integration" by Jong-Wha Lee and Kwanho Shin

21. "Is the ASEAN-Korea Free Trade Area (AKFTA) an Optimal Free Trade Area?" by Donghyun Park, Innwon Park, and Gemma Esther B. Estrada 
22. "India's Bond Market-Developments and Challenges Ahead" by Stephen Wells and Lotte SchouZibell

23. "Commodity Prices and Monetary Policy in Emerging East Asia" by Hsiao Chink Tang

* These papers can be downloaded from: (ARIC) http://aric.adb.org/reipapers/ or (ADB) http://www.adb.org/ publications/category.asp?id=2805 





\section{About the Asian Development Bank}

ADB's vision is an Asia and Pacific region free of poverty. Its mission is to help its developing member countries substantially reduce poverty and improve the quality of life of their people. Despite the region's many successes, it remains home to two thirds of the world's poor. Nearly 1.7 billion people in the region live on $\$ 2$ or less a day. ADB is committed to reducing poverty through inclusive economic growth, environmentally sustainable growth, and regional integration.

Based in Manila, ADB is owned by 67 members, including 48 from the region. Its main instruments for helping its developing member countries are policy dialogue, loans, equity investments, guarantees, grants, and technical assistance. In 2007, it approved $\$ 10.1$ billion of loans, $\$ 673$ million of grant projects, and technical assistance amounting to $\$ 243$ million.

\section{About the paper}

In this paper, Jong-Wha Lee and Ju Hyun Pyun examine the effect of trade integration on military conflict. Based on a large panel data set from 1950 to 2000, they find an increase in bilateral trade interdependence and global trade openness significantly promotes peace. They also find the impact of trade integration on military conflict varies depending on the geographical proximity: bilateral trade interdependence promotes peace more significantly for contiguous countries, while global trade openness contributes more to peace between distant countries.

Asian Development Bank

6 ADB Avenue, Mandaluyong City

1550 Metro Manila, Philippines

www.adb.org

Publication Stock No. 